Max-Planck-Institut für demografische Forschung

Max Planck Institute for Demographic Research

Konrad-Zuse-Strasse 1 - D-18057 Rostock - GERMANY

Tel +49 (0) 3812081 - 0; Fax +49 (0) 3812081 - 202;

http://www.demogr.mpg.de

MPIDR WORKING PAPER WP 2011-020

DECEMBER 2011

\title{
Census and census-like material pre- served in the archives of Hungary, Slovakia and Transylvania (Romania), 18-19th centuries
}

Péter Őri (ori@demografia.hu)

Levente Pakot (pakotlevi@yahoo.com)

This working paper has been approved for release by: Mikołaj Szołtysek (szoltysek@demogr.mpg.de), Deputy Head of the Laboratory of Historical Demography.

(C) Copyright is held by the authors.

Working papers of the Max Planck Institute for Demographic Research receive only limited review. Views or opinions expressed in working papers are attributable to the authors and do not necessarily reflect those of the Institute. 
Péter Őri - Levente Pakot

Demographic Research Institute, HCSO, Budapest

Buday L. u. 1-3. Budapest, 1024, Hungary

E-mail: ori@demografia.hu; pakotlevi@yahoo.com

Census and census-like material preserved in the archives of Hungary, Slovakia and Transylvania (Romania), 18-19th centuries

\section{Contents}

Census material from the 18-19th century Hungarian Kingdom ........................................ 2

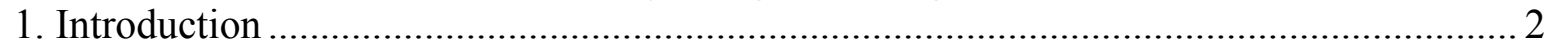

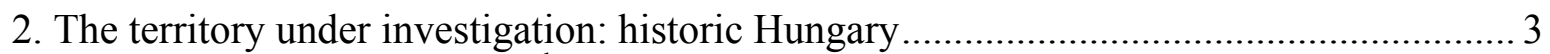

3. Census-like sources in $18-19^{\text {th }}$ century Hungary .......................................................... 5

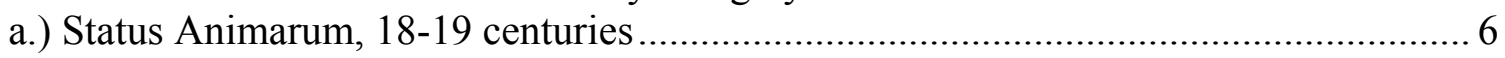

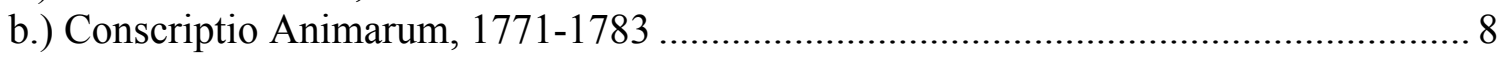

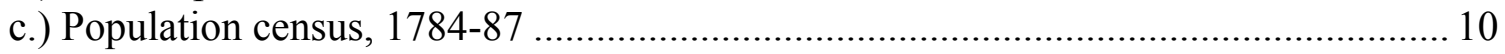

d.) Conscriptio Popularis Ignobilium (census of the non-noble population), 1804-1847 11

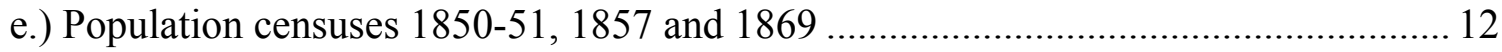

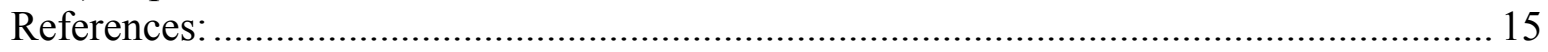

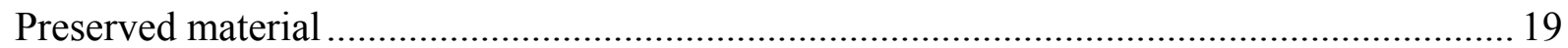

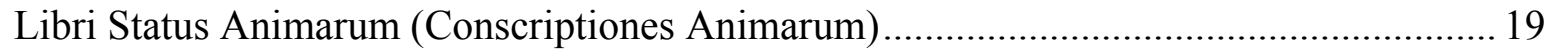

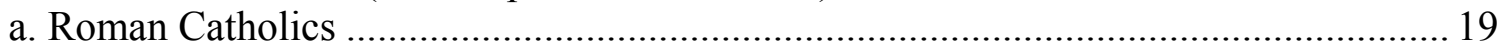

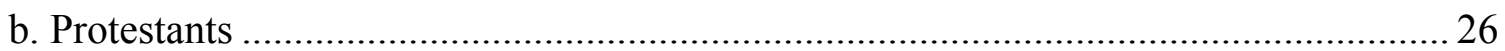

Conscriptio Animarum (1771-1784) and other census lists from the $18-19^{\text {th }}$ centuries ..... 27

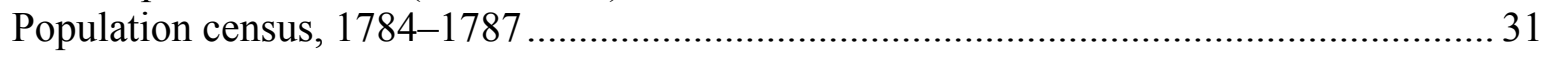

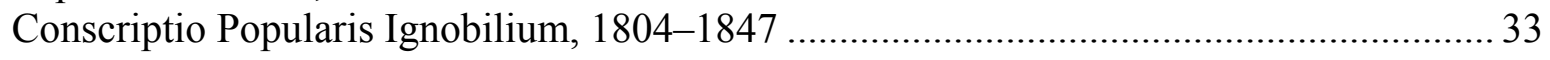

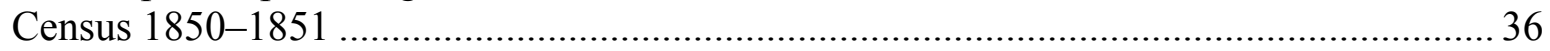

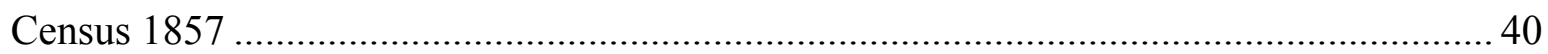

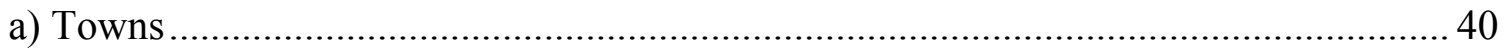

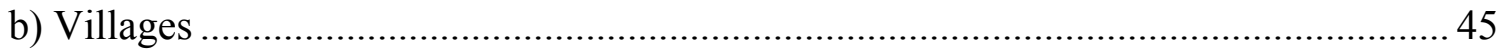

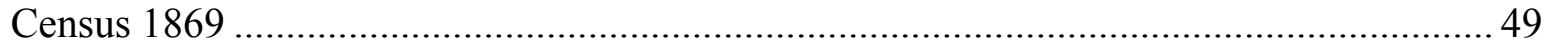

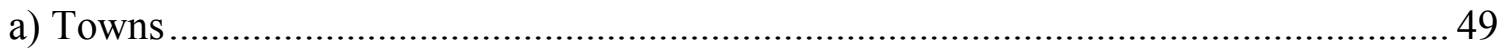

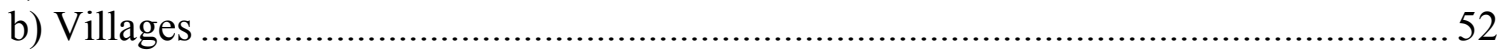

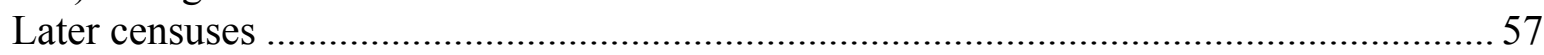

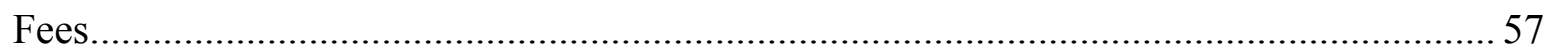




\section{Census material from the 18-19th century Hungarian Kingdom}

\section{Introduction}

Historical Hungary was the home of several ethnic and denominational groups before WW I. It was situated east of the 'Hajnal-line' but different 'western' and 'eastern' populations lived there in consequence of the medieval and early modern migratory flows. It seems to be an ideal scene for the research on household structure which may help to reply to some basic questions: whether were the evidently occurring differences caused by culture, tradition and were those cultural patterns continuously existing in the long run or were the consequences of the local systems of subsistence influenced by economic, demographic and to some extent by cultural developments. In spite of the serious destruction in historical sources, Hungarian, Slovakian and Romanian archives offer a lot of possibilities for this kind of analysis. But in order to make an account of the sources available and the research on household structure as well we should take some facts into consideration.

1. The sources suitable for historical demographic research are very similar to those of any other European countries (parish registers, population censuses, fragments of population registers carried out either by churches or the state). They resemble mainly the Austrian ones but with considerable differences. Despite the common state and ruler or common system of administration in certain periods, for example the 'Hungarian' system of population censuses was not a mechanic adoption of the Austrian one.

2. Although the Roman Catholic Church made the registration of the births, deaths and marriages as well as that of the parish members obligatory in the $16^{\text {th }}$ century, Turkish wars and occupation in the $16-17^{\text {th }}$ centuries impeded the spread of registration and caused a considerable destruction of the sources. The registration of births, deaths and marriages became general around the middle of the $18^{\text {th }}$ century while registration of the parishioners remained rare and was mainly linked to the inspections of the bishops (Canonicae Visitationes) from the second part of the $18^{\text {th }}$ century. Therefore church registers started relatively late and mostly related to one or another year or a short period, while continuous or almost continuous registers in a longer period are very rare.

3. Although the Habsburg Empire tried to establish the system of population registers based on permanently repeated enumerations of the population from the middle of the $18^{\text {th }}$ century, these initiatives remained more or less unsuccessful before the middle of the $19^{\text {th }}$ century. Enumeration of the population, particularly that of noblemen, establishing population registers or the series of censuses were always linked to the problem of privileges, taxation, conscription, generally to that of political independence. Thus population censuses often caused a considerable resistance before 1867, which did not make the process of enumeration easier and the results were sometimes regarded with doubt (especially in the case of censuses 1850/51 and 1857). This resistance or aversion to censuses explains the destruction of census material in many places at certain historical moments (for example in 1790 after the death of Joseph II). After 1867 this kind of 'constitutional' aversion disappeared, as censuses were organised and carried out by the Hungarian Statistical Office but from 1880 onwards it was precisely this professional institution which systematically destroyed all individual data after having had the anonymous summaries of the settlements.

4. A detailed inventory of the available sources has not been prepared so far. We have an old register of enumerations related only to the 'feudal' period (prior to 1848) and present-day Hungary (Bácskai 1965-1969). We cannot regard that as complete, and at the beginning of the 
investigation we knew particularly little about the preserved individual data of the censuses 1850/51, 1857 and 1869, and generally about those territories of the old kingdom, which do not belong to Hungary now. We have only very incomplete information about the census-like material preserved in the ecclesiastic archives, the inventories available on line generally do not go into details (for example one cannot know whether the material of 'Canonicae Visitationes' contains individual lists of the inhabitants or gives only a very general description of the given parish etc.). In the last two decades we witnessed a very important effort in this respect (Ördög 1991-1995): the publication of the 'Libri Status Animarum' of 305 villages and market towns from the episcopate of Veszprém (Western Hungary) having belonged to county Zala in the $18^{\text {th }}$ century but it has not modified the general picture very much.

5. Research on family history and household structure utilizing individual census data started in Hungary in the 1970s (Andorka-Faragó 1983 etc.) but it rather focused on macro-level analyses and aggregated data. ${ }^{1}$ Only some researches based at least partly on micro data covered more settlements or a smaller region (Faragó 1985; Pozsgai 2000) the other ones referred to a village or a small town chosen more or less by chance for the purpose of analysis. $^{2}$ Thus these studies cannot give an overall picture of available sources although one can have a lot of valuable information on their origin, development, content and quality as well as on the possibilities of analysing them.

Therefore, only a very thorough survey of the archive material could give a comprehensive knowledge on the availability of census micro data. Although the archive inventories, on-line information and former literature on the topic provide very important help for this work, that survey had to be based on studies made archive by archive. Only in this way we could have a view which might be considered representative for the whole Carpathian basin. The purpose of this paper is to describe the sources the inventory of which we created, and to present the surviving the material. Examining the sources and compiling their inventory we have a solid basis for choosing a representative sample for studying the household structure of the Hungarian Kingdom.

\section{The territory under investigation: historic Hungary}

The territory for which we collected data was one part of the historical Hungarian kingdom having existed before 1918 (Map 1). ${ }^{3}$ Using a geographic term, the area is sometimes mentioned as the 'Carpathian basin'. Nowadays it extends to the territories of eight countries (Hungary, Austria, Slovakia, the Ukraine, Romania, Serbia, Croatia and Slovenia). It was the home of several ethnic groups (Hungarians, Germans, Slovaks, Romanians, Serbs, Croats, Ruthens or Ukrainians and Jews etc.) and denominations (Roman and Greek Catholics, Lutherans, Calvinists, Unitarians, Orthodox, Israelites etc.). Besides ethnic and denominational diversity, the area can be characterised by geographic and economic variety: one can find the great Hungarian Plain land which was the location of extensive stock breeding (mainly cattle and sheep) or later that of wheat production, extended hilly regions with the centres of wine production or high mountains in Transylvania (now in Romania) or in Northern Hungary (now in Slovakia or in the Ukraine) where subsistence was based on extensive stock breeding (mainly sheep) or forestry.

\footnotetext{
${ }^{1}$ Some studies published in English: Andorka-Faragó 1983, Faragó 2003, Öri 2009.

2 The most interesting pieces: Husz 2002, Benda 2002, 2008, Faragó 2000, 2005.

${ }^{3}$ Officially before 1920 , the Trianon peace treaty.
} 
Map 1

The territory under investigation: historic Hungary (with recent political boarders and the administrative units of the period prior to WWI)

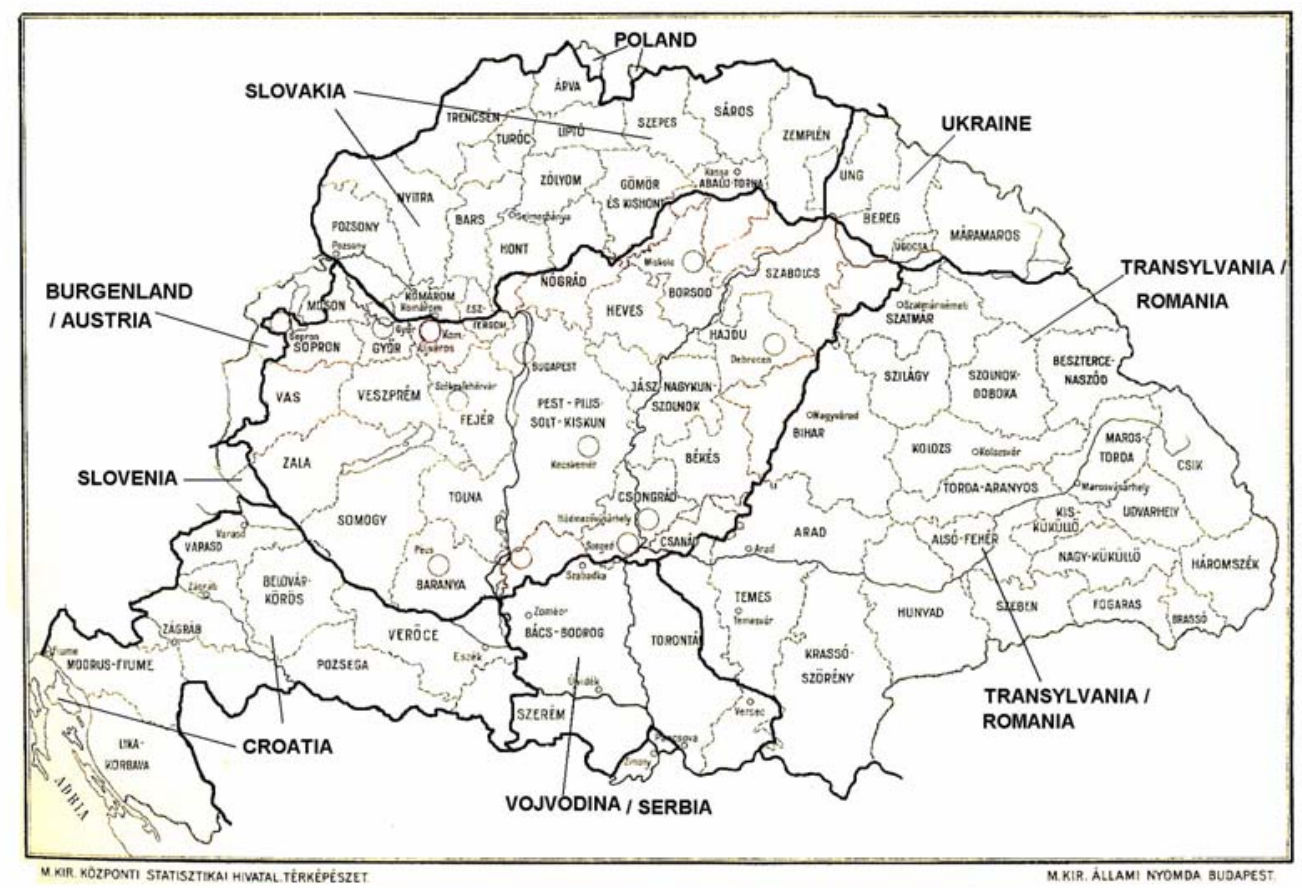

At the first step we have left the area belonging now to the Ukraine, Croatia, Slovenia and Serbia out of consideration, because the research in three countries' archives seemed to be a huge task even in itself. Besides this, because of our relationships, the information available and language skills Hungary, Romania and Slovakia appeared as possible scenery of such kind of investigation (Map 2). ${ }^{4}$ But on the basis of the experiences gained from the research, its extension to the territory of the other four countries seems to be very desirable.

With respect to the available sources, the changes of the boarders and the status of the province called Transylvania are also important. Transylvania in historical terms is not equal to the territory belonging now to Romania. It meant the region east of the counties Arad, Bihar, Szilágy, Szatmár etc (map 1 and 2), the territory beyond the so called 'Királyhágó' (Royal pass). This region was originally a part of the Hungarian Kingdom, but during the

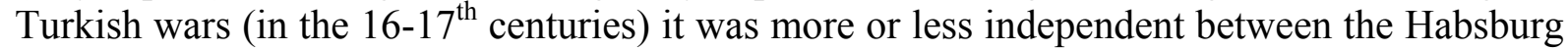
and Ottoman empires. Between 1690 and 1867 it became a Habsburg Hereditary Province which was separated from the Hungarian Kingdom. After 1867 it was reintegrated again into the kingdom. Thus the sources are the same on the whole territory of the Hungarian kingdom after 1867 but in the period prior to this date they are different a bit except for some imperial attempts to establish a population register (between 1784 and 1787) or to carry out a population census (1850 and 1857). Therefore some census-like material (for instance nonnoble censuses in the first part of the $19^{\text {th }}$ century) cannot be found in Transylvania of that strict, historic sense.

\footnotetext{
${ }^{4}$ The archive material for the territory belonging now to Austria can be found in West Hungarian archives.
} 


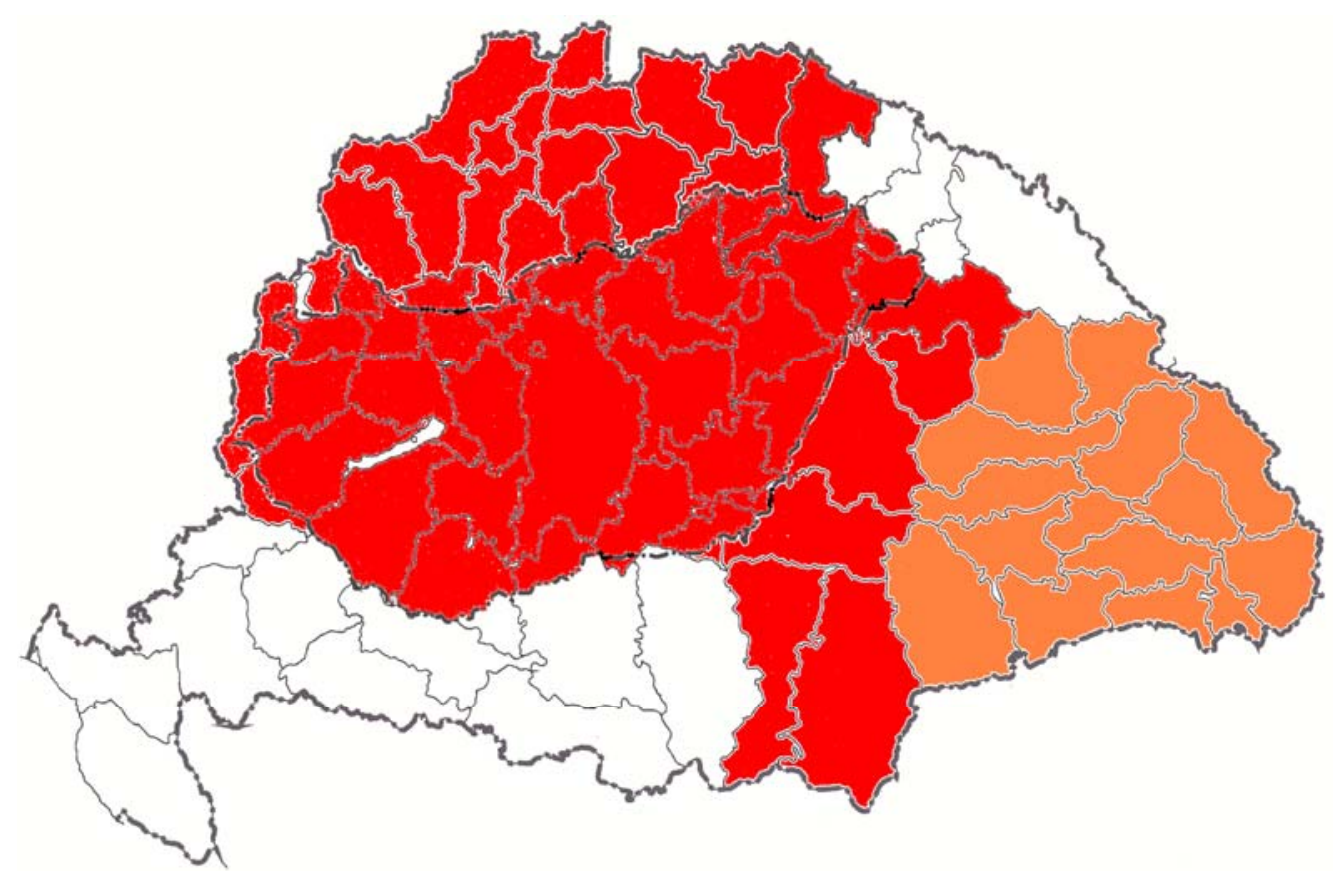

Note: coloured units: the territory under investigation; orange: the counties which formed the historic Transylvania; red: counties having belonged to the kingdom of Hungary

\section{Census-like sources in $18-19^{\text {th }}$ century Hungary}

In this part we are going to describe all those sources which can be regarded as 'population censuses' (Figure 1). In his paper on $18-19^{\text {th }}$ century German census-taking, Rolf Gehrmann tries to define the notion of census and to classify the German censuses and enumerations by the form and content of the given sources on the one hand and by the procedure of the data collection on the other (Gehrmann 2009, 4-5). He cites Willigan and Lynch's definition: "written enumeration of all individuals inhabiting a well-defined area". ${ }^{5}$ In this respect all the sources we are going to demonstrate here are population censuses with one exception. We will consider censuses those enumerations of the feudal era (in the second part of the $18^{\text {th }}$ and first part of the $19^{\text {th }}$ centuries) which left the noble population out of consideration merely because of political causes but otherwise clearly intended to register the whole rest of the population. The average proportion of the noble population was around $5 \%$ at the national level which could mean a considerable part of the population in some villages but generally does not make the reconstruction of the household structure impossible if we take a bigger sample. On the contrary, we will leave out of consideration all those sources which intended to register only a smaller part of the population although their causes and respects were very different (tax lists only with the data of tax paying household heads, censuses of the citizens of the privileged towns, those of noble, Jewish, Gypsy populations etc.).

\footnotetext{
${ }^{5}$ Willigan-Lynch 1982, 79, cited by Gehrmann 2009, 4.
} 
As for the content of the censuses taken into consideration and the procedure of the data collection, excluding early types in the 1760 s where not all persons were registered, and we can find only numeric information about servants, and some attempts to build population registers up which can be used as the basis of following censuses, all sources discussed here contain data collected from house to house and consist of the nominative lists of all individuals having resided on the studied area. ${ }^{6}$

Figure 1

Types and evolution of population censuses on the territory of Hungarian kingdom in the 18$19^{\text {th }}$ centuries

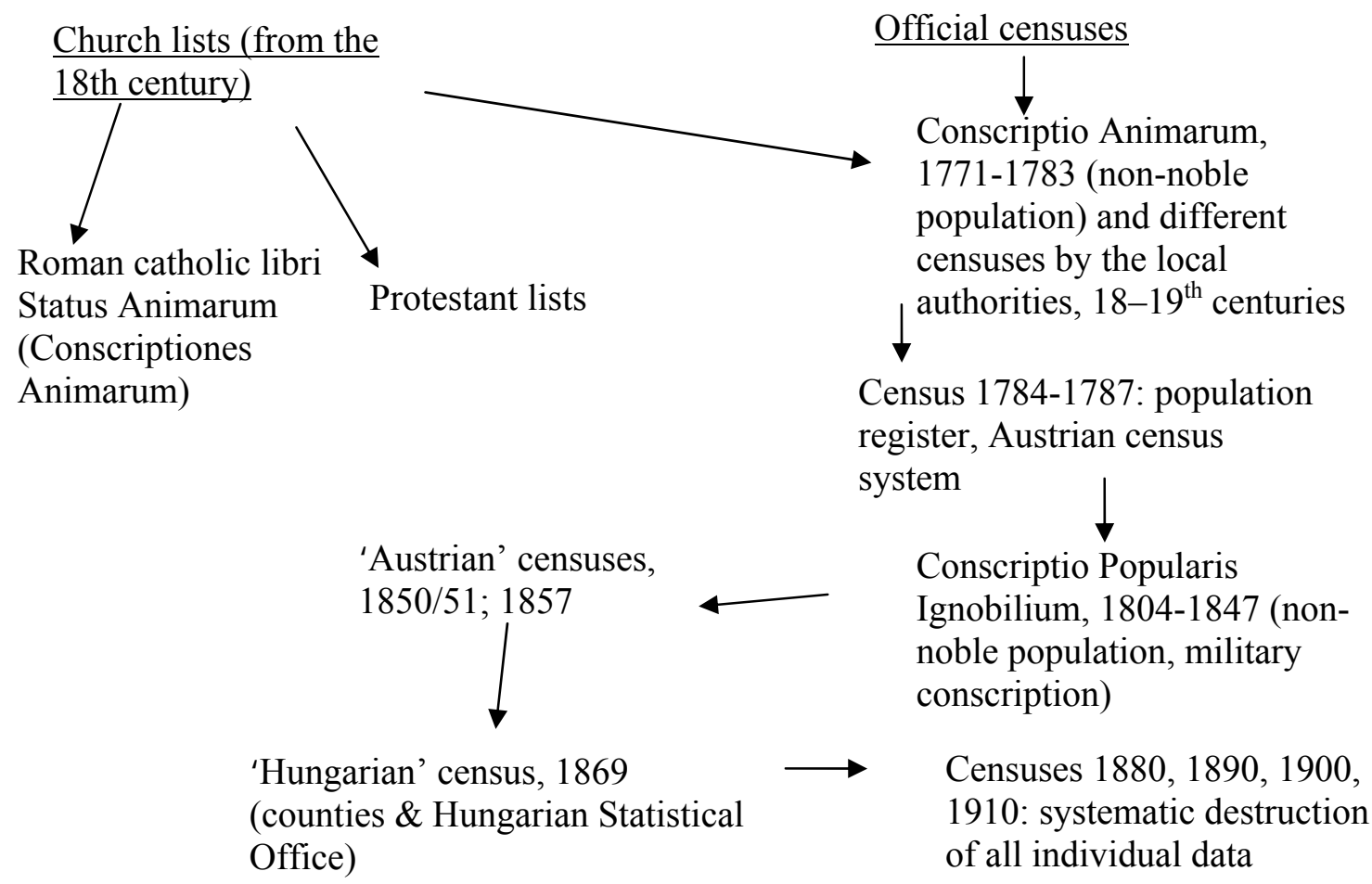

\section{a.) Status Animarum, 18-19 centuries}

In the Roman Catholic Church pope Paul V. ordered in 1614 that beside the registers of births, deaths and marriages the parsons should take a census of the population habiting their parishes (Willigan-Lynch 1982, 86-87). They had to prepare these censuses year by year, the lists contained the population by household, first they referred only to the Roman Catholics, but later they could register the whole population of a given parish. These population books (libri Status Animarum) were sometimes continuous or almost continuous, but generally were prepared when the bishop visited his episcopate (Canonicae Visitationes). This kind of household lists is well known in all Catholic countries, and a relatively rich material was preserved in Hungary too.

\footnotetext{
${ }^{6}$ The type $3 \mathrm{c}$ according to Gehrmann's classification $(2009,5)$.
} 
But if we liked to use this source, we should take some problems into account. First we can find continuous registers only in some cases. ${ }^{7}$ In most cases only one or two censuses were preserved or prepared. The other important point is the content and quality of the source. Sometimes the register means a simple nominative list of the inhabitants, without any further information on their age or family status or a clear separation of the households. In other cases households can be separated but the age of adult people was omitted, only that of minors was indicated, signing their status with respect to confession and Communion (capax/incapax coffessionis; confirmatus/ta etc.). But sometimes the lists were made as it had been prescribed, with clear separation of the households, indicating the age and family status (the relationship to the head of household) of all individuals. This kind of censuses are suitable to classify the household e.g. according to Laslett's typology. But even in these cases a lot of problems emerge. Ages are not correct in many cases, similarly, the definition and consequently the separation of households can be inconsistent etc. Sometimes we cannot decide whether people with the same name and inhabiting in separate but following households belonged really to different households or didn't. Basically a really correct analysis can be prepared only together with parish registers which make the identification of family relationships and the correction of ages indicated possible at least in one part of the cases. The lack of any indication referring to social status or profession often causes problems in the course of analysis, in other cases this kind of indication is too general or inconsistent to be used.

Libri Status Animarum can be found in the episcopal archives or in the parishes themselves. An exceptionally rich collection was prepared and preserved in the episcopate of Veszprém in the second half of the $18^{\text {th }}$ century (between 1745 and 1771). ${ }^{8}$ In Györ the lists of three villages have been preserved but for 6-10-year long periods in the second half of the $18^{\text {th }}$ century. In the archives of Kalocsa and Pécs one can find other valuable sources: especially in Kalocsa continuous series for one or another decade in the $19^{\text {th }}$ century for some villages. ${ }^{9}$ But in fact, one can easily find newer sources in the parishes, as not all the material has been collected by the Episcopal archives so far. ${ }^{10}$ This is true first of all for the territory of present-day Romania and Slovakia. Similarly, sometimes we find censuses of the Roman Catholic population in the parish registers (especially in the marriage registers).

\footnotetext{
${ }^{7}$ The best example from Hungary is the small market town of Zsámbék, close to Budapest, where nominative lists of the population for the period 1795-1867 survived, but this is an exceptional case (see: Husz, 2002).

${ }^{8}$ The material can be found partly in the episcopal archive of Veszprém partly in Székesfehérvár. One part of the censuses (from 1745, 1757 and 1769) preserved in the latter can be read on-line too: http:/www.szfvar.katolikus.hu/? $\mathrm{fm}=4 \& \mathrm{~m}=11 \& \mathrm{am}=12$. The censuses of the settlements having belonged to county Zala have been published (Ördög, 1991-1995.).

${ }^{9}$ See for example: Bárth 1975.

${ }^{10}$ The example of Zsámbék proves it clearly: the long series of census lists have been preserved in the Roman Catholic parsonage of the village.
} 


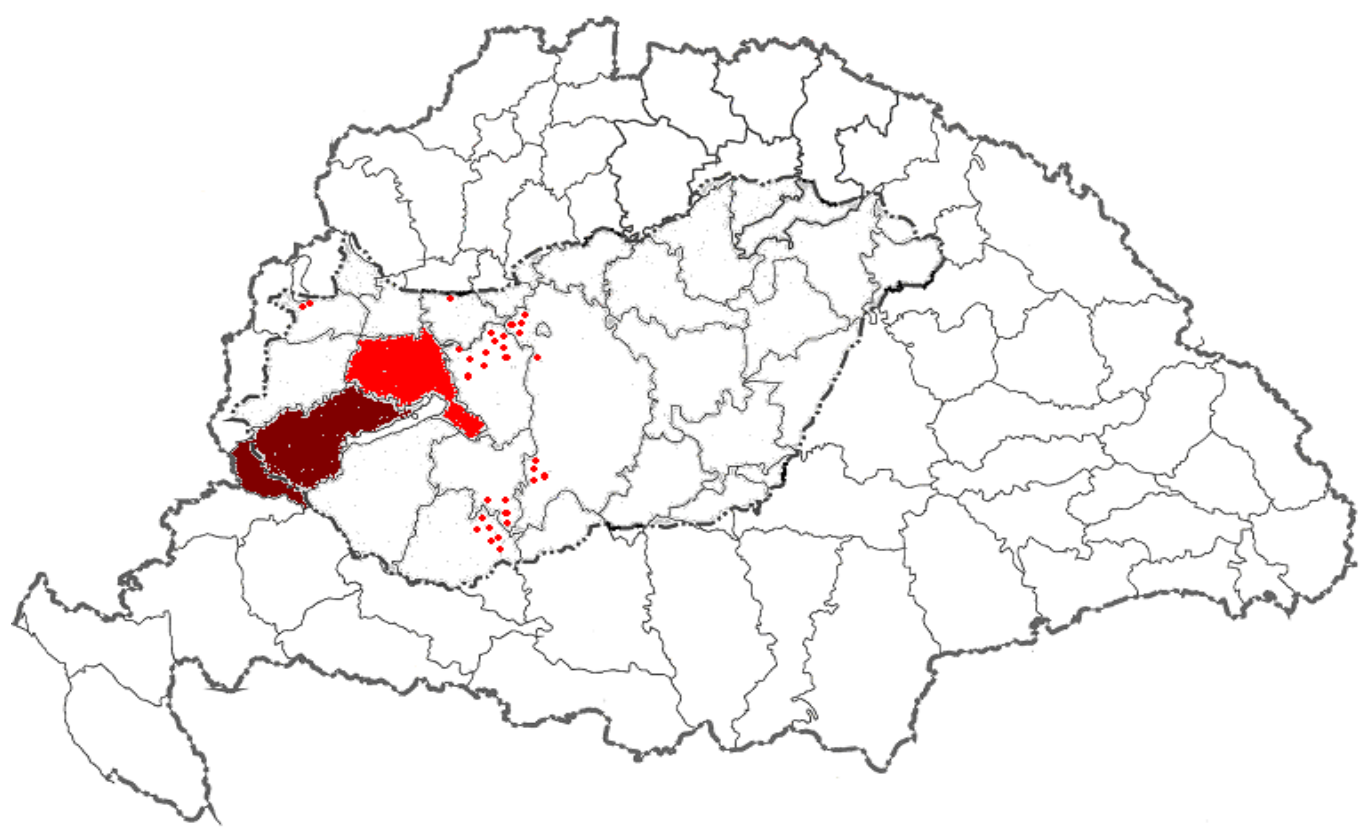

Note: coloured space: the territory belonging to the episcopate of Veszprém on which a huge amount of lists has been preserved, darker: published data (Ördög 1991-1995); spots and spotted areas: lists of some villages

We have much less information on the Protestant censuses, although they were prepared by many clergymen in the $18-19^{\text {th }}$ centuries as some well known and published or analysed household lists prove it. ${ }^{11}$ Most of them are preserved at the local parsonages while we have no sufficient knowledge on the material available in Protestant Church archives either.

\section{b.) Conscriptio Animarum, 1771-1783}

We have to distinguish between several kinds of ecclesiastic censuses (status animarum, or sometimes conscriptiones animarum) and the series of those censuses which were carried out in Hungary in the 1770s and 1780s. The latter was the Hungarian version of those censuses which were ordered in the 1750 s in the Austrian Hereditary Provinces. ${ }^{12}$ The principles and the content of the censuses were created by the government but the process of data collection was based on the practice of ecclesiastic census-taking and on the personnel of the different churches in both cases. It is also a common feature of the two sorts of census-taking that the government tried to develop them towards a system of continuous population registers first for complex governmental reasons (among them "demographic" ones also had some role) which were later substituted by the aspects of taxation and army recruiting. At the same time, there were several important differences between Austrian and Hungarian census-taking: in Hungary noble population was left out of the registration, and the categories of the censuses also differed from the Austrian ones. The cause of the differences is not quite clear but the whole process fits well into the broader political context: Hungary had a relative and

\footnotetext{
${ }^{11}$ See for example: Andorka - Balázs-Kovács, 1986; Bencsik 1977; Mándoki 1971.

${ }^{12}$ About 18th century Austrian population censuses see for instance: Durdik, 1973 and Horska, 1998.
} 
changeable "independence" within the Austrian Empire, she had her own feudal parliament and governmental institutions the intentions and opinion of which could not be left out of consideration in certain periods. Thus, the development of the census system in the second half of the $18^{\text {th }}$ century was an inherent part of the reform process of the empire but until the 1780 s, the reign of Joseph II, the Hungarian census-taking preserved its own character. ${ }^{13}$

Following the Austrian practice of census-taking, the procedure of registration was tested on the royal estates from 1765 onwards. ${ }^{14}$ The leading staff of the estates registered the population household by household, distinguishing persons owning houses from those without ownership and classifying them by profession (peasant and artisans) and indicating the status of the members of the households (wives, children, servants). In the prescribed formula there was no place for relatives living in the households (brothers, sisters, widowed persons) so we may suppose that they have been partly or entirely omitted in the course of the registration. Later ownership or profession was not indicated but the age of the registered appeared on the lists. This version also intended to register the nuclear families where servants had their own rubric neither. But sometimes we find summaries of the settlements at the end of the nominative lists where the number of servants and widowed persons was indicated broken down by age groups and denomination. At the end of 1760s the summaries of the births, deaths and marriages as well as in- and out-migration also appeared by very complicated categories: the number of the annual growth and decrease was broken down by denomination, broad age-groups, social categories, the character of the events (births or inmigration and deaths or out-migration also detailed in further categories etc.). Because of the evident shortages of the registration the real size of the population cannot be revealed and household composition cannot be analysed on the basis of this source.

Having drawn the conclusion from these experiences, the Hungarian Chancellery formed the system of the census-taking which existed in the country until 1783. The local clergymen annually registered the non-noble population household by household, indicating the age, family and social status of the inhabitants. They prepared the summaries of the settlements (taking the laic administrative boarders into account ${ }^{15}$ ) classifying the population by broad age groups (under and above 15), sex, special social categories and denomination. They also compiled the tables of increase and decrease which were basically the simplified versions of the tables having appeared in the 1760s. The summarizing tables were simplified further in 1780 but the principles did not change until $1783 .{ }^{16}$ The clergymen had to send the summarizing tables of the settlements to the counties the officers of which prepared the summaries of the counties while the superior authorities created the national summary which was sent to the royal court through the Chancellery. In consequence of this procedure, one can find the national summaries in the Hungarian National Archives for some years $(1777,1781$, 1782), ${ }^{17}$ and the summaries of the counties in many regional archives for several years. One part of the material was obviously lost or destroyed, another part was not prepared but it is a huge material suitable for macro-level demographic analysis. The quality of the censuses became better and better after the first years, clergymen got used to this kind of registration. ${ }^{18}$

\footnotetext{
${ }^{13}$ About the Hungarian Conscriptiones Animarum see: Fügedi, 1966; Dányi, 1993; Öri 2003.

${ }^{14}$ See in Hungarian National Archives, Archives of the Royal Chamber, E 160, Diversae Conscriptiones.

${ }^{15}$ They summarized not the data of their parishes but those of the settlements belonging to their parishes. In the case of the larger settlements the summarizing tables were prepared by the cooperation of several clergymen sometimes belonging to several denominations. Therefore the procedure of summarizing was very complicated, and provided a lot of possibilities for making mistakes.

${ }^{16}$ About the development of Conscriptio Animarum see: Öri, 2003.

17 Their analysis is in Dányi, 1993.

${ }^{18}$ During the 1770 s a lot of supplementary data appeared in the local parish registers, for instance remarks on the socio-professional status of the dead or age at marriage which were requested in the summarizing procedure of
} 
We may suppose that sometimes one part of the population was omitted beside noblemen and their households, especially the registration of the population living in scattered hamlets or temporary residences on the plain land or among mountains could be problematic. Similarly the rate of these lacks also correlates with that of migration (Öri, 2003, 148), proving that migration also caused problems. But otherwise we have no evidence for the systematic omission of one or another part of the population, naturally excluding noble population.

Most part of the nominative material was lost, but some interesting fragments were preserved (e.g. the registers of some streets from the town of Debrecen for the years 17711776 and those of some towns and villages from the 1770s). The lists usually contain the data of household heads by house and name, household members only by sex, age group (adults, under 15) and denomination (only by their number).

Similar censuses were prepared later too, in the $19^{\text {th }}$ centuries, which were preserved in the local archives the purpose of which has not been clarified yet. They seem to have been prepared by the local authorities and preserved in the archives of the counties or towns. Among them we have to mention the census lists of 21 villages from a small region close to the Croatian boarder from 1842 (County Somogy and Baranya), or the household list of the town of Hódmezővásárhely from 1850-52, or the censuses prepared in some towns in 184849. All these censuses can be used for the purposes of the analysis of household structure although they usually do not contain information on socio-professional status.

\section{c.) Population census, 1784-87}

The system of census-taking entirely changed in 1784. Changes happened in harmony with the reforms in the course of which Joseph II. tried to unify the monarchy with the more or less total integration of the Hungarian part. Instead of the separate registration system the Austrian practice was set up in Hungary. It meant the inclusion of noble population into the enumerations therefore that of 1784-87 was the first, "modern" population census in the history of the country which intended really to count the whole population. At the same time, not only the target population but the whole content, method and practice of the census-taking changed entirely. As the system of military conscriptions set up in the Hereditary Provinces in the 1770s was extended to the Hungarian part, census-taking serving for military purposes also appeared in Hungary. The government aimed at establishing a population register on the basis of which the number and spatial distribution of males suitable for military service could be pointed out. Civil authorities counted the inhabitants in parallel with military ones settlement by settlement and household by household. In the course of the registration each household has got an own sheet containing the data of household members: name, age (only in the case of males), qualification (position in the household, socio-professional status, stature and other physical character in the case of males etc.). At the same time, enumerators had to classify people into prescribed categories relating to sex, marital status, some socioprofessional categories, indicating the character of their stay (local people or foreigner), and the permanent absence of the household members. As for females, only their marital status and foreign status had to be signed and a special, much simpler household sheet contained the data of Israelite population. Connecting the separate household sheets the enumerators created the population books (Populationsbücher) of the settlements from which one copy should have remained in the given settlement to register all changes (births, deaths and migration). On the basis of the population books the non-nominative summaries of the settlements were prepared where each household had a separate line. Summarising the data of those lines the summary of the settlement could be calculated. Summing up these data the summaries at

the demographic events. After the end of this kind of obligatory census-taking, in the 1790s e.g. the indication of age at marriage disappeared for a long time. 
county and national level were prepared while the military authorities made their summaries by recruiting regions. Thus, based on a census, a continuous population register would have been set up which would have given a possibility to explore the number of males suitable for military service and to check their moves, at least in theory. ${ }^{19}$ After having registered all changes during the year a so called revision (revisio, Evidenzhaltung) could check and modify the population books in the course of which the data of civil and military books would have been brought in line.

The new system had to be set up in Hungary by the help of military force. The basic census was carried out in 1784-85. The individual household sheets were mostly lost or destroyed, generally the summaries of the counties or those of the settlements were preserved. In spite of all troubles, the census is generally regarded as reliable, particularly with respect to population size or the number of houses and households, marital status etc. The whole registration system however was rather a failure in Hungary. First, after 1787 the work stopped as the political situation became more and more serious. Second, although we do not know exactly the functioning of the system, there are a lot of evidences that it did not work in such a way as it had been imagined and prescribed. Civil and military authorities did not cooperate, their data were never reconciled, and population changes were not registered continuously, at most in the bigger towns. We have a lot of lists indicating the changes of the population of a given settlement (births, deaths, migrating persons) which can prove that changes were registered separately and population books were corrected only once or twice a year, in the course of the revision. Although we have the country-wide summary from 1787 and a lot of summaries at county level in many regional archives, it is not quite clear whether the revisions carried out in 1786 and 1787 were real enumerations or simple corrections made on the basis of the lists of changes. Therefore, the results gained from the census 1784-85 are generally considered more reliable. We can conclude that the basic data are reliable and suitable for analysis: on the individual sheets the size and composition of the households, position in the household, age etc. In all probability, the registration of changes worked more or less well, but the classification of people which could alter as a consequence of many events (ageing, marriage, migration, death of the head of household or a brother, social mobility etc.) must have been a very problematic thing. Therefore, the social categories of the non-nominative summaries are very uncertain, classification was based on the judgement of the enumerators or sometimes was the product of local self-identification (Benda, 2008). Sometimes the sudden changes in the proportions from one year to another show that continuous re-classification or the altering definitions caused a lot of troubles. ${ }^{20}$ But we have to emphasize that all these problems refer to one part of the data and appear first of all at aggregated level, preserved local population books are the best $18^{\text {th }}$ century sources to analyse household structure at individual level. Unfortunately, only fragments have been preserved from the original household sheets. The most significant part of the material is the censuses of three towns: Györ in Hungary (circa 13,000 inhabitants), Prešov (Eperjes) in Slovakia (circa 6,000 inhabitants) and Tîrgu Mureş (Marosvásárhely) in Transylvania (circa 5,000 inhabitants). Beside that, only the censuses of three villages have been preserved.

\section{d.) Conscriptio Popularis Ignobilium (census of the non-noble population), 1804-1847}

\footnotetext{
${ }^{19}$ As for the the censuses see: Thirring, 1931, 1938; Dányi-Dávid, 1960; Öri 2002, 2003a

${ }^{20}$ For example the proportion of the foreigners decreased considerably between 1785 and 1787 at each aggregated level as a consequence of changing definition: in 1784-85 definition was not clear, classification was very inconsistent and exaggerated, but by 1787 it had been clarified that after a 10 -year permanent stay everybody became a local resident.
} 
After the death of Joseph II. the system of census-taking changed again. After a longer pause the Hungarian feudal diet (parliament) decided to set up a newer series of censuses in 1802 . This kind of enumerations also served for military purposes but an important difference showed the changing political situation: noble population and clergymen were omitted again. According to the decision local clergymen and administrative personnel registered the nonnoble population, in this respect this newer enumeration resembled Conscriptio Animarum. On the other hand, the questionnaire was rather similar to that of the census of Joseph. The enumeration should have made every year but generally it did not happened, there are considerable lacks even in the relatively well preserved materials. In some cases we may also suspect that newer enumerations were not prepared in the reality but only former census data were corrected on the basis of the changes or were copied in a very obvious way. Thus the first some enumerations can be considered reliable but the quality of the source generally worsened as time elapsed.

The enumeration was made household by household, some data were recorded for each person while others only for males. Thus name, year of birth and household position (relationship to the head) was written down in every case, obviously all household members were registered including servants too. Similarly, every person was classified as resident people or foreigner. On the contrary, age was recorded only in the case of males, only males were separated by socio-professional groups, which were much clearer and better defined than in the case of $18^{\text {th }}$ century censuses, by broad age groups, marital status, denomination, presence or absence (in the country, out of the country, on an unknown place). Individual lists survived more seldom, although compared to the census 1784-87 this kind of source was preserved better and sometimes can cover whole micro-regions The censuses of some towns remained: Buda, Cegléd, Nagykőrös, Makó, Hajdúszoboszló are worth mentioning, beside this the census material of a region nowadays belonging partly to Hungary, partly to Austria has been preserved (in county Sopron). But in each case only one or two censuses remained, there are no longer series suitable for longitudinal analysis.

\section{e.) Population censuses 1850-51, 1857 and 1869}

After the revolution and independence war a newer era of centralization followed from 1849 onwards. As a consequence, two population censuses were carried out by the authorities of the centralised empire which aimed at the registration of the whole population (excluded the members of the army). The first one began in 1850 but the effective work of enumeration ended only in 1851 . The results were regarded with doubts, according to generally accepted estimations about $5-6 \%$ of the population was left out of the records (Dányi, 1993a, 8). The following census in 1857 seems to have been more successful and reliable.

The work of enumeration was carried out by houses, within the houses so called Wohnpartei were separated as the basic units of registration. The notion of Wohnpartei also used in the course of following censuses differed a bit from the former notion of household (familia). According to the instructions Wohnpartei means: a.) marital couples with or without child/ren; b.) widowers or widows with child/ren; c.) single or widowed persons without child/ren who have servants and live alone on their fortune, office or income (Dányi, 1993a, 92). It is also clear that foster children and other relatives living together also had to include into the notion of Wohnpartei. On the basis of this, it seems to be not probable that Wohnpartei would have been equal to nuclear family according to the original intentions as some authors state it (Pozsgai, 2000, 173). It is much more probable that the newer unit of enumeration must have been close to former household concept (the community of persons living, farming, working and consuming together) at least in most cases (Benda, 2002, 131). But without any doubt, "household" notion became less certain, and left room for inconsistent 
interpretation and practice. On the basis of the experiences gained from the analysis of the 1869 census of Kiskunhalas, we may conclude that Wohnpartei means household in most of the cases, but sometimes households might have been divided by unknown aspects (in the case of houses with more Wohnpartei). In such cases mostly widowed or single persons were cut down from nuclear families or were separated from one another. We do not know the logic of this division but it was not automatic, e.g. the proportion of extended family households was also considerable (Öri, 2005, 284). One has to act carefully analysing household composition utilising these censuses, but especially in the villages where most of the houses was inhabited by one unit (Wohnpartei) this problem can be surely resolved.

In 1850 first the name of the owner of the house was recorded (he or she got the first place if he or she lived in the given house). After that followed the serial numbers of the inhabitants: first the head and his wife or a widowed person, after their sons and daughters and other relatives (see the problem of Wohnpartei). Name, year of birth, rank, office or profession and denomination, marital status and at first time nationality was also recorded. Character of stay, presence and absence was signed at each person while only males were classified according to age groups.

We can find very considerable surviving materials of some towns: Tîrgu Mureş (Marosvásárhely) in Romania, Košice (Kassa) in Slovakia, Makó, Magyaróvár, Hajdúnánás, Hajdúszoboszló, Kiskunlacháza, Bonyhád and some frafments, all in Hungary, but the rural material is rather poor consisting of the censuses of six villages (all in Hungary).

In 1857 the exact date of the enumeration was fixed (October 31), nationality was omitted, an exact date of birth was demanded, prescribed categories were used for the classification by profession, the representatives of both sexes were put into age categories but females had less and broader age-groups than males. Otherwise the questionnaire was quite similar to that of 1850. Two types of sheets survived: the original ones (Aufnahmsbogen), and the preliminary registration sheets in the towns on which the house-owners could register the inhabitants (Anzeigezettel) and on the basis of which the census sheets were prepared. The latter ones contain the same information but profession was written down freely and the given person was classified later on the census sheet according to pre-printed categories based on the information of Anzeigezettel. Beside this, Anzeigezettel indicated the number of domestic animals while Aufnahmsbogen didn't, about them separate sheet was prepared similarly to residing foreigners.

The amount of surviving material is very considerable (Map 4). The material of many towns remained with more or less lacks: Buda, Győr, Székesfehérvár, Szentes, Túrkeve, Baja, Kecskemét, Cegléd, Magyaróvár in Hungary, Tîrgu Mureş, Satu Mare, Baia Mare in Transylvania (Romania). At this time the rural archive material is also significant and suitable for having a national-wide sample: the material for whole counties or regions has been preserved, beside separate cases. Thus, we have the census sheets for the territory of counties Sáros (379 villages in Slovakia) and Abaúj-Torna (134 villages in Hungary, 123 villages in Slovakia). Very important surviving materials remained in county Maros (Transylvania, 165 villages), Zemplén (17 villages, mostly in Slovakia), Nógrád (54 villages in Slovakia), Sopron (16 villages in Hungary, 51 in Austria), Tolna (8 villages in Hungary), Csanád (32 settlements, most of them in Hungary, some of them in Romania), Esztergom (3 villages in Hungary, 2 in Slovakia). 


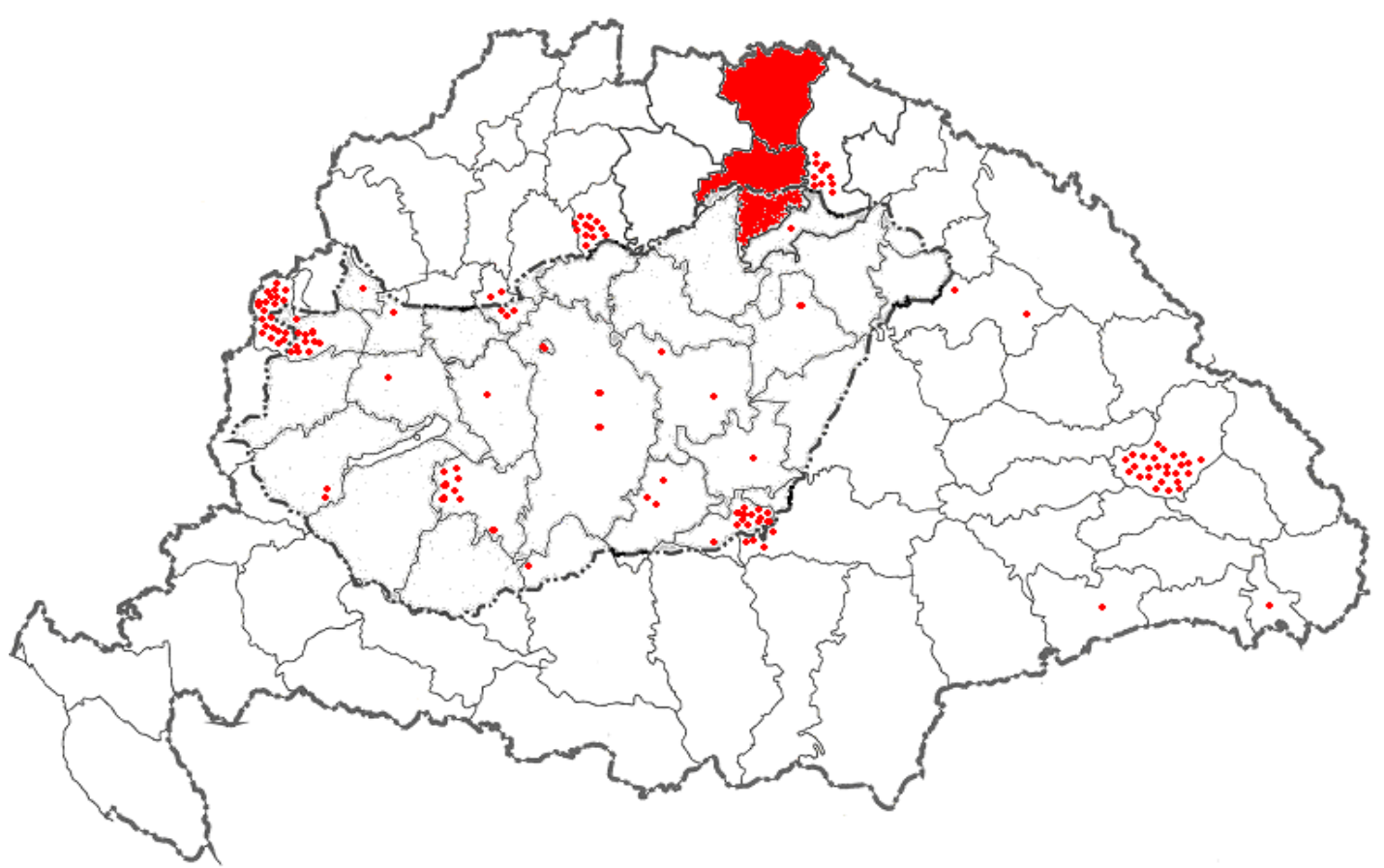

Note: coloured space: surviving census sheets for the whole territory of the given county; spots or spotted areas, surviving material for separate settlements or smaller regions

After the compromise of the Austrian and Hungarian political elite the first census carried out by the independent Hungarian Statistical Office followed in 1869 (its exact date was December 31 1869). In the course of the census, an enumeration of domestic animals was also carried out as some data of the flats/houses were recorded. The enumeration was made house by house in which every flat has got a separate sheet for registering the inhabitants by household/Wohnpartei. Name, rank, sex, denomination, profession or the character of employment/profession, place of birth, status (resident or foreigner), presence and absence (longer or not than 1 month), literacy was recorded, in the column of remarks notes could be made on physical disability, military service, place of residence in case of foreigners, place of stay in case of absent persons.

A very large amount of individual data can be found sometimes for whole regions, counties or towns. The urban material contains the entire or almost entire censuses of the towns of Debrecen, Győr, Székesfehérvár, Szentes, Túrkeve, Magyaróvár, Kecskemét in Hungary or Braşov (Brassó) and Tîrgu Mureş (Marosvásárhely) in present-day Romania. The whole material of the following counties remained: Torna (35 villages), Bars (212 villages), Nyitra (494 villages), Komárom (103 villages), Sáros (386 villages), Szepes (189 villages), Zemplén (463 villages), Zólyom (120 villages). Very considerable material remained in county Maros (100 villages), Pozsony (55 villages), Szilágy (39 villages), Háromszék (6 villages), Esztergom (8 villages), not listing here some separate cases (Map 5). We have certain information on the surviving material of county Ung in present-day Ukraine, but we did not search in the Ukrainian archives, this information has to be still confirmed. 


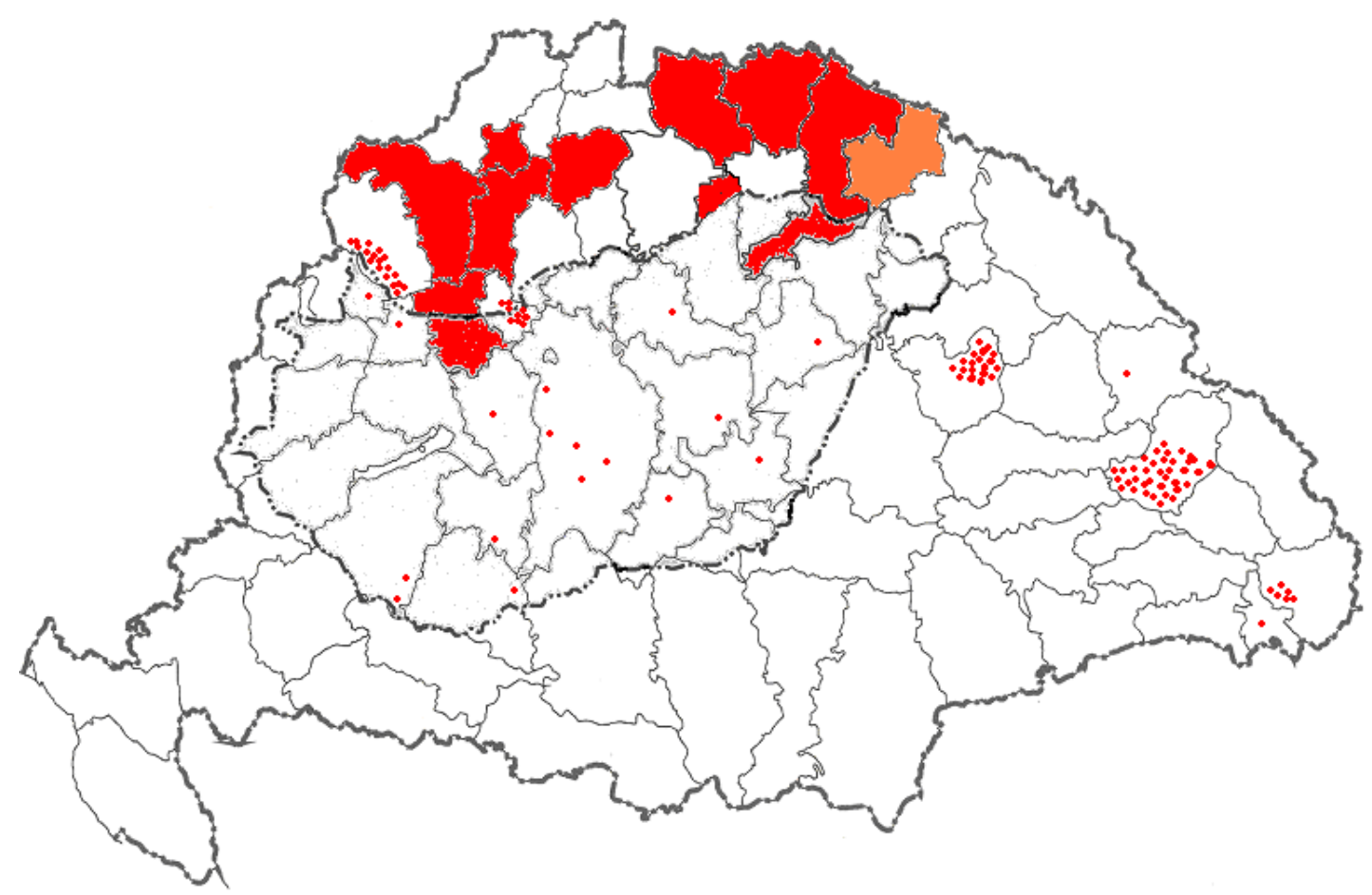

Note: coloured space: surviving census sheets for the whole territory of the given county (orange: county Ung belonging to present-day Ukraine); spots or spotted areas, surviving material for separate settlements or smaller regions

Particularly these three latter professional censuses appear to be suitable for choosing a country-wide sample for the analysis of household composition, especially the material of censuses 1857 and 1869 are very promising concerning data availability. It is worth mentioning that until 1880 all censuses were carried out by the help of local administrative authorities (data collection and summing up was made by counties) so many individual census lists can be found in the regional archives. From 1880 onwards the work was entirely undertaken by the professional statistical service, and individual data were destroyed professionally. It is almost impossible that individual sheets will appear somewhere from $1880,1890,1900$ or 1910 . There are some nominative lists of inhabitants from some places from 1880 which served as a basis for census-taking but they contain only reduced information on population. Although some exceptional material survived from later periods too, for instance the census 1941 for Budapest, it is quite clear that a sampling of micro-data of households should concentrate on the period prior to 1880 .

\section{References:}

Andorka, Rudolf - Balázs-Kovács, Sándor (1986): The Social Demography of Hungarian Villages in the Eighteenth and Nineteenth Centuries (with Special Attention to Sarpilis, 1792-1804). Journal of Family History, vol. 11. no. 2. pp. 169-192. 
Andorka, Rudolf - Faragó, Tamás (1983): Pre-industrial Household Structure in Hungary. In Laslett, Peter - Wall, Richard (eds.): Family Forms in Historic Europe. Cambridge: Cambridge University Press, pp. 281-307.

Bácskai, Vera (ed.) (1965-1969): A területi levéltárakban őrzött feudális kori összeírások jegyzéke. [The inventory of feudal registers preserved in regional archives] I-III. Budapest: Müv. Minisztérium Levéltári Osztálya.

Barth, János (1975): Fajsz népessége a XVIII. század közepén [The population of Fajsz in the middle of the $18^{\text {th }}$ century] In Iványosi-Szabó, Tibor (ed.): Bács-Kiskun Megye múltjából I. Kecskemét, pp. 81-131.

Bencsik, János (1977): Csege szabadmenetelü jobbágyfalu társadalomrajza a XVIII-XIX. század fordulóján. [The society of Csege, free village at the turn of the $18-19^{\text {th }}$ centuries] In Nyakas, Miklós (ed.): A Hajdúsági Múzeum Évkönyve, III. Hajdúböszörmény: pp. 63149.

Benda, Gyula (2002): A háztartások nagysága és szerkezete Keszthelyen, 1757-1851. [The size and structure of the households in Keszthely, 1757-1851], In Faragó, Tamás - Öri, Péter (eds.): KSH NKI Történeti Demográfiai Évkönyve, [Historical Demographic Yearbook] Budapest: KSH NKI, 2002. pp. 109-141.

Benda, Gyula (2008): Zsellérböl polgár. Keszthely társadalma, 1740-1849. [From serf getting citizen. Keszthely's society, 1740-1849]. Budapest: L'Harmattan.

Dányi, Dezső (1993): A hazai népesség és népesedésstatisztika kezdetei. [The beginnings of the Hungarian population statistics], KSH NKI Történeti Demográfiai Füzetek 12. pp. 107290.

Dányi, Dezső (1993a): Az 1850. és 1857. évi népszámlálás. [Population censuses in 1850 and 1857]. Budapest: KSH.

Dányi, Dezső - Dávid, Zoltán (1960): Az első magyarországi népszámlálás (1784-1787), [The first population census in Hungary (1784-1787)], Budapest: KSH Könyvtár - Magyar Müv. Minisztérium Levéltári Osztálya.

Durdik, Christel 1973. Bevölkerungs- und Sozialstatistik in Österreich im 18. und 19. Jahrhundert. In Helczmanovszki, Heimold (ed.): Beiträge zur Bevölkerungs- und Sozialgeschichte Österreichs. Wien: Verlag für Geschichte und Politik, pp. 225-266.

Faragó, Tamás (1985): Paraszti háztartás- és munkaszervezet-típusok Magyarországon a 18. század közepén. Pilis-Budakörnyéki háztartások 1745 és 1770 között. [Types of peasant household structure and labour force system] (Történeti Statisztikai Füzetek 7.) Budapest: $\mathrm{KSH}$.

Faragó, Tamás (2000): Miskolc város népessége a 18. század eleje és a 19. század közepe között. [The population of the town of Miskolc between the beginning of the 18th century and the middle of the 19th century] In Faragó, Tamás (ed.): Miskolc története [The history of Miskolc] III/1. 1702-1847. Miskolc: BAZ Megyei Levéltár, pp. 151-272.

Faragó, Tamás (2003). Different Household Formation Systems in Hungary at the End of the 18th Century: Variations on John Hajnal's Thesis. Demográfia, 46, Special Edition, pp. 95-136.

Faragó, Tamás (2005): Életciklusok és családmodellek egy magyarországi városban a 18-19. században. [Life cycles and family models in a Hungarian town in the $18^{\text {th }}$ and $19^{\text {th }}$ centuries]. Demográfia, 48/4. pp. 415-435. 
Fügedi, Erik (1966): A 18. századi lélekösszeírások története. [History of the 18th century census of the souls] Demográfia, 9/3. pp. 366-378.

Gehrmann, Rolf (2009): German Census-Taking before 1871. (MPIDR Working Paper WP 2009-023 August 2009), Rostock: MPIDR.

Horska, Pavla 1998. Les populations autrichiennes jusqu'en 1914. In Bardet, Jean-Pierre Dupâquier, Jacques (eds.): Histoire des populations de l'Europe 2. La révolution démographique, 1750-1914. Paris: Fayard, pp. 439-453.

Husz, Ildikó (2002): Család és társadalmi reprodukció a 19. században. Történetiszociológiai tanulmány egy Buda-környéki mezöváros társadalmáról a családszerkezet változásának tükrében, [Family and social reproduction in the 19th century. A historicalsociological survey concerning the society of a market town near Buda in the mirror of changes in family structure], Budapest: Osiris.

Mándoki, László (1971): A kölkedi népszámlálás, 1816 [Census in Kölked, 1816]. Janus Pannonius Múzeum Évkönyve, 13. Pécs: pp. 215-224.

Ördög, Ferenc (ed.) (1991-1995): Zala megye népességösszeirásai és egyházlátogatási jegyzőkönyvei (1745-1771) [Libri Status animarum and Canonicae Visitationes in county Zala] I-IV. Budapest Zalaegerszeg: MTA Nyelvtudományi Intézete - Zala megye Önkormányzati Közgyülése.

Öri, Péter (2002): Hatalom és demográfia. II. József népszámlálása Magyarországon I. [Power and demography. Joseph II's population census in Hungary I]. Faragó, Tamás - Öri, Péter (eds.): KSH NKI Történeti Demográfiai Évkönyve [Historical Demographic Yearbook], 2002. pp. 39-73.

Öri, Péter (2003): A demográfiai viselkedés mintái a 18. században. Lélekösszeirások Pest megyében, 1774-1783. [Patterns of demographic behaviour in the 18th century. Censuses in county Pest, 1774-1783], (KSH NKI Kutatási Jelentések, 75), Budapest: KSH NKI.

Öri, Péter (2003a): Demográfia elméletben és gyakorlatban. II. József népszámlálása Magyarországon II. [Demography in theory and practice. Joseph II's population census in Hungary II]. KSH NKI Történeti Demográfiai Évkönyve[Historical Demographic Yearbook], 2003. pp. 89-127.

Öri, Péter (2005): Kiskunhalas népessége 1869-ben [The population of Kiskunhalas in 1869]. In Ö. Kovács, József - Szakál, Aurél (eds.): Kiskunhalas története 3. Tanulmányok Kiskunhalasról a 19. század közepétöl a 20. század közepéig. [The history of Kiskunhalas. Studies on Kiskunhalas, from the middle of the 19th century to the middle of the 20th century]. Kiskunhalas, pp. 269-292.

Öri, Péter (2009): Marriage Customs and Household Structure in Hungary at the end of the 18th Century. The Case of County Pest-Pilis-Solt (1774-1785). In Fauve-Chamoux, Antoinette - Bolovan, Ioan (eds.): Families in Europe between the 19th and 21st Centuries. From the the Traditional Model to the Contemporary PACS. (Supplement of the Romanian Journal of Population Studies). Cluj-Napoca: Cluj University Press, pp. 167192.

Pozsgai, Péter (2000) Család, háztartás és tulajdon Torna vármegyében a 19. század második felében. [Family, household and property in county Torna in the second half of the 19th century]. In Faragó, Tamás - Öri, Péter (eds.): KSH NKI Történeti Demográfiai Évkönyve, [Historical Demographic Yearbook] Budapest: KSH NKI, pp. 166-224.

Thirring, Gusztáv (1931): II. József magyarországi népszámlálásai. [Joseph II’s population censuses in Hungary]. Magyar Statisztikai Szemle, IX/2. pp. 112-134. 
Thirring, Gusztáv (1938): Magyarország népessége II. József korában. [The population of Hungary during the reign of Joseph II], Budapest.

Willigan, J. Dennis - Lynch, Katherine A. 1982. Sources and Methods of Historical Demography. New York, London etc.: Academic Press. 


\section{Preserved material}

\section{Libri Status Animarum (Conscriptiones Animarum)}

\section{a. Roman Catholics}

\section{Győri Püspöki Levéltár (Episcopal Archive in Győr, Hungary)}

www.gyor.egyhazmegye.hu

9021 Györ, Káptalandomb 5/A.

Tel.: +36 96-513-175

Fax.: +36 96-550-741

e-mail: arch.dioc.gyor@gmail.com

- The Roman Catholic parish of Fertőszéplak, HU (3 villages: Fertőszéplak, Hegykő and Sarród - County Sopron; Roman Catholic population with some Jewish families)

Data: all members of households, house by house, name, age, capax/incapax confessionis, households separated, no data on household membership, but the order of members is continuous (head, wife, children, servants and others, with family names)

Conscriptio capacium et non capacium ab 1762 - without other identification

Years: 1763 (Fertőszéplak 105 houses, Hegykő 74 houses, Sarród 65 houses)

1765

1766

1767

1768

1769

1770-1771

1772

1779

1781 (without Sarród)

- Conscriptio Animarum in Sopronkövesd, HU 1762-1829

Roman Catholic village with circa 800 inhabitants (County Sopron)

Data: all members of households, house by house, name, age, capax/incapax confessionis, households separated, no data on household membership, but the order of members is continuous (head, wife, children, servants and others, with family names)

Years: 1762

1763

1766 (without age)

1768 (without age)

1769 (without age)

1770 (without age)

1772

1773 (only the heads by name)

1774 (age not complete)

1779

1780

1784 (without age)

1788 (without age)

1791 
1793 (without age)

1812 (without age)

1829 (without age)

- Conscriptio Animarum in the Roman Catholic Parish of Szőny, HU (Szőny village + Almásfüzítő and Ad Trajectum outskirts: 168 houses in 1780, County Komárom)

Data: see above

Years: 1763

1765 .

1766 .

1772 .

1774.

1777.

1778 .

1779 .

1780 .

\section{Kalocsai Érseki Levéltár (Archiepiscopal Archive in Kalocsa, Hungary)}

http://archivum.asztrik.hu

6300. Kalocsa, Szentháromság tér 1.

Tel.: +36 78-462-166

Fax: +36 78-465-280

E-mail: archivum@ $\underline{\text { asztrik.hu }}$

The photo-copies of parish registers and household lists can be downloaded from the webpage of the archive. The fee is $4000 \mathrm{HUF} /$ three months. Original copies are in the parishes.

The list of the material:

http://archivum.asztrik.hu/sites/default/files/letoltesek/dig dok nyilv_plebania.xls

- Conscriptio Animarum of Roman Catholic village of Dusnok, HU (589 households, 2892 inhabitants in 1869 - county Pest-Pilis-Solt-Kiskun) V. 39. Dusnok, vol.: 311-314

Data: all members of households, house by house, name, age, capax/incapax confessionis, households clearly separated, relationship to household head and family status indicated.

Years: 1853 - 402 households

1855 - 390 households

1861 - 491 households

1863 - 503 households

- Status Animarum in Roman Catholic, German village of Hajós, HU (800 households and 3829 inhabitants in 1869 - county Pest-Pilis-Solt-Kiskun) V. 51. Hajós, vol.: 283-284

Data: all members of households, house by house, name, age, capax/incapax confessionis, households clearly separated, status of children is not indicated but they follow their parents, heads' social status, profession, widowhood, servant status is indicated.

Years: $1820-352$ households

1821 - 361 households

1822 - 368 households

1823 - 378 households

1824 - 391 households

1825 - only one page with two households

1826 - 396 households, some missing pages 
- The 'family book' of Hajós, 1890-1914 - married couples and their children house by house with the date of their birth, marriage and death

- Conscriptio Animarum in the Roman Catholic village of Jánoshalma,HU (1304 households and 7890 inhabitants in 1869 - county Bács) V.59. Jánoshalma, vol.: 114-124

Data: all members of households, house by house, name, age, capax/incapax confessionis, households clearly separated, status of children is not indicated but they follow their parents, the status of non-relatives in the households is not always indicated

Years: $1827-1829-857$ households

$1834-891$ households

1838 - 846 households

1851 - 957 households

1852 - 959 households

1854 - 974 households

1856 - 976 households

1862 - 1251 households

$19^{\text {th }}$ century without year -1216 households

$19^{\text {th }}$ century without year -1250 households

- Status Animarum in the archi-episcopal centre of Kalocsa, HU (2932 households, 16302 inhabitants in 1869, mainly Roman Catholic: 15645) centre of the town: V.61. Kalocsa belváros, vol.: 364

Data: all members of households, house by house, name, age, capax/incapax confessionis, households clearly separated, relation to head is indicated, social categories too, age is sometimes missing.

Year: $1790-682$ households in the centre of the town

- Conscriptio Animarum in the Roman Catholic town of Kiskunfélegyháza, HU (one parish from the centre) V.76. Kiskunfélegyháza, Óplébánia vol.: 68

Data: not from every year, only the name of the household heads or the married couples, other members of the households only by number

Years: 1761-1803

- Conscriptio Animarum in the Roman Catholic village of Mélykút, HU (1519 households, 6153 inhabitants in 1869, county Bács) V. 94. Mélykút, belterület, vol.: 118

Data: all members of households, house by house, name, age, capax/incapax confessionis, households clearly separated, relation to the head is indicated

Year: 1823547 households + hamlets and outskirts

- Conspectus Animarum in the Roman Catholic village of Nemesnádudvar, HU (504 households, 2039 inhabitants in 1869, county Pest-Pilis-Solt-Kiskun) V. 100. Nemesnádudvar, vol.: 303

Data: alphabetic order of inhabitants,_age, number of house, then status animarum from 1857, all household members, households separated, age, household position clearly indicated, then the register of the inhabitants by the order of the date of birth until 1929 with the date of death Year: 1857-1929

1857 - 307 households

- Status Animarum Fajsziensium - Fajsz, HU Roman Catholic village close to the town of Kalocsa, (165 households) I. Canonicae visitationes, Fajsz, 
Data: all household members with marital status, age, capax/incapax cofessionis, confirmati or not, relationship to household head

Year: 1762

Published by: Barth, János: Fajsz népessége a XVIII. század közepén [The population of Fajsz in the middle of the $18^{\text {th }}$ century] In Iványosi-Szabó, Tibor (ed.): Bács-Kiskun Megye múltjából I. Kecskemét, 1975. pp. 81-131.

- Register of married couples in Dunapataj, HU first half of the $20^{\text {th }}$ century, Roman Catholics

Data: couples with age, profession, educational status, birth place, date of marriages, children with birth date, co-residing relatives and employees

- Register of married couples in Dunaszentbenedek, HU 1926-1927, Roman Catholics

Data: couples with age, profession, educational status, birth place, date of marriages, children with birth date, co-residing relatives and employees as in the case of Dunapataj

\section{Pécsi Püspöki Levéltár (Episcopal Archive in Pécs, Hungary)}

http://www.pecs.egyhazmegye.hu/gyujtemenyek.html

7624 Pécs, Szent István tér 23.

Tel.: +36 72 513-030/3120

E-mail:ppkl@ordinariat.hu

K 16-19 (1753-1783) - four volumes of census lists (status animarum)

One part of the material consists only of summaries, one part of nominative lists.

Data: in the latter cases households separated, all members with marital status, age

More considerable material has remained in the villages as follows:

Bonyhád, Cikó, Zsibrik, Nagymányok, Lak, Nyárád, Majs, Bóly, Mohács, Siklós - in counties Baranya and Tolna

\section{Székesfehérvári Püspöki Levéltár (Episcopal Archive in Székesfehérvár, Hungary) www.szfvar.katolikus.hu 8000. Székesfehérvár, Városház tér 5. \\ Tel.: +36 22 510-697 \\ Fax: +36 22 510-699 \\ E-mail: mozessyg@ szfvar.katolikus.hu or leveltar@szfvar.katolikus.hu}

All status or conscriptiones animarum preserved in the archive from the years 1745,1757 , 1769 can be downloaded for free from the web-site of the archive using a searching system (on the basis of the year or name of the village),:

http://www.szfvar.katolikus.hu/?fm=4\&m=11\&am=12

This part means almost the total of the material preserved, some later fragments also will be digitalised by the archive.

Data: quality is very varied. Sometimes we can find simple lists of the inhabitants, sometimes households can be separated and sometimes all members are on the lists with age, household position etc. Here we listed only those ones where households are clearly separated, and age and household membership can be found. Generally household members' family names were omitted so some members' relationship to the head is uncertain (servants, in-mates).

bold: villages with several lists 
1745.

Bakonysárkány (117AB/aa) 43 households - county Fejér

Csákvár (117AB/h) 104 households - county Fejér

Érd (117AB/1) 153 households, - county Fejér

Piliscsaba (117AB/g) 70 households - county Pest-Pilis-Solt

Pilisvörösvár (117AB/kk): 195 households - county Pest-Pilis-Solt

Solymár (117AB/bb) 111 households - county Pest-Pilis-Solt

Sóskút $(117 \mathrm{AB} / \mathrm{cc}) 137$ households - county Fejér

Zámoly $(117 \mathrm{AB} / \mathrm{mm})$ circa 30households - county Fejér

Zsámbék (117AB/nn) circa 290 households - county Pest-Pilis-Solt

1757.

Bicske (117AC/a) 217 households (with filiae) - county Fejér

Bodajk (117AC/b) circa 250 households - county Fejér

Csákberény $(117 \mathrm{AC} / \mathrm{c}) 62$ households + filiae - county Fejér

Csákvár (117AC/d) 153 households - county Fejér

Csór (117AC/e) 93 households - county Fejér

Etyek (117AC/g) 125 households - county Fejér

Iszkaszentgyörgy $(117 \mathrm{AC} / \mathrm{h}) 81$ households - county Fejér

Lovasberény (117AC/i) 144 households - county Fejér

Mór (117AC/k) 554 households - county Fejér

Szár (117AC/m) 110 households - county Fejér

Vál (117AC/n) 208 households (with filiae) - county Fejér

1768.

Pátka (117A/bb) circa 88 households - county Fejér

1769.

Pázmánd (117A/m) 132 households - county Fejér

Zsámbék (117AD/dd) circa 400 households - county Pest-Pilis-Solt

5. Váci Püspöki Levéltár (Episcopal Archive in Vác, Hungary)

http://www.vaciegyhazmegye.hu

2600 Vác, Migazzi Kristóf tér 2.

Tel. +36 $27814-141$

Fax.: +36 $27814-101$

E-mail: leveltar@vaciegyhazmegye.hu

The archive has an independent collection named:

I.1.bn Numerus Animarum, 1769-1944

Unfortunately this huge amount of archive material contains only few nominative sources, all those were made in the second half of the $18^{\text {th }}$ century. Most of the sources consist of the lists of marital couples indicating their age and social status (nobiles, plebei and servi - noblemen, serfs and servants). In other cases we can find complete households without the indication of age and social status or couples with names but widowed persons, servants, foreigners only by their numbers. The lists were prepared mostly for compiling the annual summarising tables demanded by the Habsburg administration, the categories used clearly prove it. Those summarising tables were preserved in a large number in the archive. 
Only the list of one village contains complete households with all members, indicating names, age and relationship to household head:

Pereg, 1777 - a Roman Catholic parish (94 households) - maybe a smaller part of the population was omitted (according to the census in 1785: 119 houses, 179 households, 930 inhabitants).

Beside this one can find other lists at the parishes as the material (original copies of parish registers, household lists and Historiae Domus) hasn't been collected by the archive so far.

\section{Veszprémi Érseki Levéltár (Archiepiscopal Archive in Veszprém, Hungary) http://vel.veszprem.hu/ 8200 Veszprém, Vár u. 16. \\ Tel: +36 88 426-088 \\ Fax: +3688 426-287 \\ E-mail: leveltar@ersekseg.veszprem.hu, leveltar.ersekseg@gmail.com}

The archive has the largest collection of Libri Status Animarum in Hungary. In the second half of the $18^{\text {th }}$ century, during the episcopate of Márton Padányi Bíró a series of descriptions and household lists were made about the parishes among which some were of excellent quality and contained not only Roman Catholic population but Protestants too. The material can be found in two archive collections: I/A/8 Visitationes Canonicae and I/A/14 Conscriptiones Animarum. While the latter one consists of nominal lists, the first contains mainly the description of the parishes but in some cases it went together with preparing household lists too. One part of the material was given to the Diocese of Székesfehérvár which was founded on the territory of the Diocese of Veszprém in 1777. This material has been preserved in the archive in Székesfehérvár (see above). In the collection Visitationes Canonicae (prepared between 1745 and 1750) there are no repetitions while in the collection Conscriptiones Animarum several lists were preserved for a lot of settlements. This huge material cannot be described here in detail, the table presented here gives the years of listing, and the number of settlements (parishes) of which household lists have been preserved. As for the quality of the sources we cannot make general announcements: it can differ year by year and village by village as the experiences gained from the lists preserved in the archive of Székesfehérvár prove it. Generally the later censuses $(1769,1771)$ are regarded as of better quality while between 1745 and 1748 in many cases only the married couples and their children were registered (the nuclear families) and widowed persons were listed separately referring or not to the number of house in which they lived. But in other cases we find entire households where the status of each member is indicated. At the same time, in 1757, 1769 or 1771 there is no indication of household status which makes the identification of co-residing household members very difficult. Similarly, one part of the households may be missing but that must be clarified case by case.

\section{Household lists in the Diocese of Veszprém}

\begin{tabular}{|l|c|}
\hline Year & Number of settlements \\
\hline I/A/8 Visitationes Canonicae & \\
\hline 1745 & 44 \\
\hline 1746 & 92 \\
\hline 1747 & 109 \\
\hline 1748 & 284 \\
\hline $1746 / 1748$ & 1 \\
\hline 1749 & 50 \\
\hline
\end{tabular}




\begin{tabular}{|l|c|}
\hline 1750 & 2 \\
\hline 1751 & 8 \\
\hline I/A/14 Conscriptiones Animarum \\
\hline 1745 & 165 \\
\hline 1746 & 56 \\
\hline 1748 & 17 \\
\hline 1750 & 1 \\
\hline 1751 & 6 \\
\hline $1752 / 1757$ & 7 \\
\hline $1753 / 1756$ & 3 \\
\hline $1753 / 1757$ & 2 \\
\hline $1756 / 1757$ & 1 \\
\hline 1757 & 820 \\
\hline 1758 & 6 \\
\hline 1760 & 3 \\
\hline $1765 / 1770$ & 5 \\
\hline 1766 & 1 \\
\hline 1767 & 1 \\
\hline 1769 & 66 \\
\hline 1770 & 76 \\
\hline 1771 & 469 \\
\hline 1775 & 1 \\
\hline 1776 & 27 \\
\hline 1777 & 6 \\
\hline 1778 & 6 \\
\hline 1779 & 5 \\
\hline 1780 & 1 \\
\hline
\end{tabular}

The censuses relating to the territory of historical county Zala has been published (the data of 305 settlements):

Ördög, Ferenc (ed.) (1991-1995): Zala megye népességösszeírásai és egyházlátogatási jegyzökönyvei (1745-1771) [Libri Status animarum and Canonicae Visitationes in county Zala] $I-I V$. Budapest - Zalaegerszeg: MTA Nyelvtudományi Intézete - Zala megye Önkormányzati Közgyülése.

\section{Status or Conscriptiones Animarum in the parish registers or in the Roman Catholic parishes}

Beside the ecclesiastic archives one can find valuable materials, household lists written into the registers of marriages or births or libri Status Animarum or family books preserved in the parishes themselves.

- Roman Catholic parish of the town of Hódmezővásárhely (county Csongrád, HU)

Data: only the Roman Catholic minority, households clearly separated, age, status in the family (wife, children, widowed persons, somebody's mother, servant etc. indicated)

Years:

1745 - 64 households, 228 inhabitants

1755 - 80 households, 366 inhabitants 
1778 - 310 households, 2036 inhabitants

(population size in 1785: 2980 households, 15,773 inhabitants, in 1869 circa one fifth part of the population is Roman Catholic, in 1778 this proportion must have been smaller)

- Roman Catholic parish of Nagykáta (county Pest-Pilis-Solt, HU)

Magyar Országos Levéltár, Mikrofilmtár [Hungarian National Archive Microfilms] nro. 5179

Roman Catholic parish registers of Nagykáta, vol. II, Mixed registers ('verschiedenes' registers) pp. 207-326 - Status Animarum

Data: households separated, age, social status indicated

Years:

1764 - 359 households

1779 - 228 households - not entire

- Roman Catholic parish of Zsámbék (county Pest-Pilis-Solt, HU)

Original copies in Zsámbék in the Roman Catholic parish

Data: households separated, age, marital status, status in the households indicated

Years:

1795 (435 households), 1796, 1797, 1798, 1799, 1800, 1801, 1802, 1803, 1812, 18131814 , $1815,1817,1818,1820,1821,1823,1824,1825,1828,1829,1830,1831,1832,1833,1834$, $1836,1842,1845,1847,1850,1852-53,1859,1860,1862-63,1865,1867$ (490 houses, circa 600 households)

1785 census: 364 houses, 470 households

1869 census: 480 houses, 787 households

Published analysis:

Husz, Ildikó: Család és társadalmi reprodukció a 19. században. Történeti-szociológiai tanulmány egy Buda-környéki mezöváros társadalmáról a családszerkezet változásának tükrében, [Family and social reproduction in the 19th century. A historical-sociological study on the society of a market town near Buda in the mirror of changes in family structure], Budapest: Osiris, 2002. p. 170

\section{b. Protestants}

- Calvinist parish of Tiszacsege (county Hajdú, HU)

Original in the parish of Tiszacsege

Published by: Bencsik, János: Csege szabadmenetelü jobbágyfalu társadalomrajza a XVIIIXIX. század fordulóján. [The society of Csege, free village at the turn of the $18-19^{\text {th }}$ centuries] In Nyakas, Miklós (ed.): A Hajdúsági Múzeum Évkönyve, III. Hajdúböszörmény: 1977. pp. 63-149.

Year: 1808 - 261 households

\section{Library of TÁRKI, Budapest}

Budaörsi út 45. X/1006.

Andorka Rudolf library

1/a Családrekostitúciós vizsgálatok adatai [Data of family reconstitutional studies]

Box 42. (original copies in the parishes)

- Sárpilis, Calvinist parish (county Tolna, HU)

Data: households separated, all members (with servants etc.), age of parents often missing, generally no data about social status or position in the household

Year: 
$1792-85$ households

1804 - 99 households

- Alsónyék, Calvinist parish (county Tolna, HU)

Data: households separated, all members but age is not indicated

Year: $1792-122$ households

- Mezőcsoknya, Calvinist parish (county Somogy, HU)

Data: households separated, all members with date of birth and marriage, status in the household (relation to head)

Year: $1800-91$ households

- Kölked, Calvinist parish (county Baranya, HU)

Data: households separated, all members with age, status in the household (relation to head)

Year: $1816-110$ households

Published by: Mándoki, László: A kölkedi népszámlálás, 1816 [Census in Kölked, 1816]. Janus Pannonius Múzeum Évkönyve, 13. Pécs: 1971. pp. 215-224.

\section{Conscriptio Animarum (1771-1784) and other census lists from the $18-19^{\text {th }}$ centuries}

\section{Conscriptio Animarum (1771-1784)}

The census was ordered by the government and was carried out by clergymen and local administrative units (counties and towns). Its aim was the establishment of a continuous population register in harmony with the Austrian census-taking system. Roman Catholic priests and the clergymen of other denominations made the work of census-taking based on parish registers and ecclesiastic censuses of the population. The original nominative lists on the basis of which the summarizing tables were prepared by the counties' authorities were generally lost. Most of them contain the names of the house-owners or the married couples or in some cases those of their children but relatives, widowed persons and servants were registered only by their number. The whole system was tested on the royal estates in the 1760 s and the largest material preserved in the archives of the Royal Chamber.

Magyar Országos Levéltár, Kamarai Levéltár, E 160. Conscriptiones diversae, 1-8

[Hungarian National Archive, Archives of the Royal Chamber]

Magyar Országos Levéltár [Hungarian National Archive]

www.mol.gov.hu

1014 Budapest, Bécsi kapu tér 2-4.

Tel: +36 12252840

Fax:: +3612252817

E-mail: nagykutato@mol.gov.hu

Census lists from the Royal estates, 1764-1767

Data: one part of the household members were omitted (widowed persons, relatives, servants), in some cases only nuclear families (married couples and their children), widows, widowers and servants only by number in summarizing tables

In some cases (from 1766-1767) the data are suitable for analysing the structure of households containing house by house household heads by name, their age and denomination, 
the age and denomination of their wives, the number of children, widowed persons, servants by denomination and two age groups (adults, under 15)

- e.g. The censuses of the Royal Estate of Visegrád, 1766 and 1767

E 160. 5 .

(market town of Visegrád, villages of Nagymaros, Kismaros, Kóspallag, Zebegény and Kisoroszi; all in $\mathrm{HU}$ )

\section{Other preserved lists:}

Békés Megyei Levéltár [Archive of county Békés]

www.bekes-archiv.hu

5700 Gyula, Petöfi tér 2.

Tel.: +36 20 289-8909

E-mail: leveltar@bekes-archiv.hu

- Szeghalom village 1773 (HU)

The archive of Szeghalom, V/335

- Füzesgyarmat village, 1774, 1777 (HU)

The archive of Füzesgyarmat, V/314

Data: heads by house and name, household members only by sex, age group (adults, under 15) and denomination (by their number)

\section{Hajdú-Bihar Megyei Levéltár [Archive of county Hajdú-Bihar]}

http://hbmleveltar.hu.

4024 Debrecen, Vármegyeház utca 1/B

Tel.: +36 52 507-550/642

fax: $+3652507-550 / 638$

E-mail: leveltar@hbml.hu

- The town of Debrecen, the household lists of streets Hatvan, Piac, Czegléd, Csapó, Varga, 1774 (HU)

IV. A. 1011/t, the documents of the town of Debrecen, census lists, 1693-1826

Data: see above Szeghalom and Füzesgyarmat

Győr város levéltára [The archive of the town of Győr HU]

www.vleveltar.gyor.hu

9024 Györ, Rákóczi Ferenc u. 1.

Tel: +36 $96312-288$

E-mail: leveltar@enternet.hu.

XV/5. Népösszeírások levéltári gyüjteménye, 1784-1870 [Collection of population censuses]

1. Conscriptio Animarum

1. 1819-1823

2. $1824-1827$

3. $1828-1830$

Data: see above Debrecen etc.

Komárom-Esztergom Megyei Levéltár [Archive of county Komárom-Esztergom] www.kemarchiv.hu 
2501 Esztergom, Vörösmarty u. 7.

Tel.: +36 33 500-405; +36 33 400-768

fax: +36 33 500-406

E-mail: kemarchiv@mail.iif.hu

- The town of Esztergom, 1762, 1793-1796, 1800-1801, 1806/1807, 1810, 1812 (HU)

IV.1001/c, censuses

Data: see above Debrecen etc.

Bács-Kiskun Megyei Levéltár, Kiskunhalas város levéltára [Archive of county BácsKiskun, archive of the town Kiskunhalas]

www.bacs-kiskun-leveltar.hu

6400 Kiskunhalas, Paprika Antal u. 12-14.

Tel/Fax: +36 30/630-0499

E-mail: leveltar@bacs-kiskun-leveltar.hu

- The town of Kiskunhalas, 1770/1771 (HU)

V.201/d összeírások (censuses)

Data see above Esztergom etc. + census of corn production (Conscriptio Animarum et omnis generis frugum)

\section{Pest Megyei Levéltár, Nagykőrös [Archive of county Pest in Nagykőrös, HU]}

www.pestmlev.hu

2750 Nagykőrös, Hősök tere 4.

Telefon: +36 53 350-492

e-mail: postmaster@pmlnagykoros.t-online.hu

V.202/e The documents of the town of Nagykörös

Box 1: The town of Nagykörös, 1771 (HU)

Data: see above Debrecen, Esztergom etc.

\section{Somogy Megyei Levéltár [The archive of county Somogy]}

www.smarchive.hu

7400, Kaposvár, Rippl-Rónai tér 1.

Tel.: +36-82-528-200, +36-82-429-923

fax: $+36-82-314-347$

IV.45/d Népszámlálás, 1842 [Population census, 1842]

The household lists of 21 villages from the southern part of historic county Somogy, nowadays most of them belong to county Baranya (HU)

Data: all household members by name, age indicated only in the case of males, denomination, relation to household head indicated, in some cases the social status of household head also given

Year: 1842

Villages: Bürüs (39 households), Drávakeresztúr (37 households), Drávafok ( 99 households), Drávaszentmárton (124 households, 982 inhabitants), Gárdony (51 households), Gyöngyösmellék (108 households), Hobol (84 households), Kastélyosdombó (101 households), Lakócsa (85 households), Potony (32 households), Markócz (32 households), Révfalu (18 households), Magyarújfalu (44 households), Németújfalu (60 households), 
Okorág (67 households), Sellye (140 houses), Sztára (71 households, 664 inhabitants), Tótújfalu (75 households), Várad (19 households), Szörény (25 households), Zádor (70 households)

\section{Csongrád Megyei Levéltár, Hódmezővásárhelyi Levéltára [Archive of county Csongrád in Hódmezővásárhely HU]}

$\underline{\text { www.csml.hu }}$

6800 Hódmezővásárhely, Bajcsy-Zsilinszky E. u. 25.

Tel.: +36 62 222-308;

E-mail:leveltar@hodtav.hu

IV.B. 1106/c Hódmezővásárhely város tanácsánal iratai, Népszámlálási iratok [Documents of the town of Hódmezővásárhely, Population censuses]

1. doboz (box 1) 1850-1852 - census of the town flat by flat - entire (made district by district)

Data: number of house; name of the household members; age; number of rooms; all household members, relation to head is indicated (wife, child, widowed parent, servant, etc.) circa 7,000 houses

\section{Budapest Főváros Levéltára [The Archive of Budapest]}

http://bfl.archivportal.hu/

1139 Budapest, Teve u. 3-5.

Tel: +36 298-7503, +36 298-7504

E-mail: bfl@bparchiv.hu

V.1./i. Óbuda város Tanácsának iratai [the documents of the town of Óbuda], Népszámlálások [Population censuses]

1-5. Population census from 1848, houses 1-751 (circa 10,000 inhabitants)

Data: name denomination and age of inhabitants house by house, profession of household heads, journeymen, servants and apprentices only by their number

6. household heads by name and profession, from 1849

7. school-age children from 1849, name of the household head, number of children by agegroup,

8. journeymen in 1849, name, birth place, age, marital status, denomination, profession, address, employer

9. servants in 1849, data: see as above in the case of journeymen

10. 1849: address, name of household head, profession, since when has he lived there, number of other household members

IV.1106/d. Buda város Tanácsának iratai [The documents of the town of Buda],

Különféle népesség,- ingatlan,- és állatösszeírások [Different population, immovable property and animal censuses]

2. Population census from 1848 by districts: Vár, Viziváros, Tabán, Krisztinaváros, Újlak, Data: address, name of the inhabitants, without age, households separated within the houses, status in the household indicated

Viziváros (Wasserstadt): 809 houses, 11,846 inhab.

Krisztinaváros (Christinastadt): 502 houses, 4,195 inhab.

Tabán: 950 houses, 9,544 inhab.

Vár (Burg): houses 113-227, 2,319 inhab. 
3. Census from 1848 (cont.)

Vár (Burg): houses 1-112, 2,345 inhab.

Országút (Landstrasse): 395 houses, 4,235 inhab.

Újlak (Neustift): 401 houses, 4219 inhab.

Census of the suburb Ujlak (Neustift) in 1860: 381 houses

Data: house number, name, age, social status, sex, denomination, married couples, all household members, status within the household indicated

4. Census of the suburb Újlak (Neustift) from 1873

Houses 1-180

5. Census of the suburb Újlak (Neustift) from 1873

Houses 181-376

Data: printed sheets, address, name of inhabitants, age, the profession of household heads, relation to the head in the case of other members (wife, son, daughter, servant, etc)

\section{Population census, 1784-1787}

It is regarded as the first real population census aiming at registering all the population. It would have been the basis of a continuously functioning population registration which served first of all for military purposes just like in the Austrian Hereditary Provinces. Unfortunately the individual sheets of the census-taking remained only in a very small number.

Data: individual sheets are unified, house number, name of the house-owner, names of the inhabitants, age (only in the case of males), relation to the head, social status/profession of the head, absence and presence by some categories

\section{Győr város levéltára [The archive of the town of Győr HU]}

www.vleveltar.gyor.hu

9024 Györ, Rákóczi Ferenc u. 1.

Tel: +36 $96312-288$

E-mail: leveltar@enternet.hu.

XV/5. Népösszeírások levéltári gyüjteménye, 1784-1870 [Collection of population censuses] 2. II. József-kori népszámlálás Györre vonatkozó adatai 1784/85 [Data of the population census relating to the town of Györ, from the age of Joseph II, 1784/85]

Volumes 1-10: seems to be entire with smaller possible lacks, circa 1600 houses, 3000 households, 13000 inhabitants

\section{Štátny oblastný archív, Prešov [Regional State Archive in Prešov/Eperjes, SLO]}

Slanská 31, 08006 Prešov - Nižná Šebastová

Tel.: 091-7460052 - ústredňa, 091-7460055 - bádatel'ňa

Fax: 091-7764059

E-mail: archiv@sapo.vs.sk

XXIV.1. Magistrát Mesta Prešov, sčítacie hárky, 1784 [The original sheets of the census 1784 from the town of Prešov/Eperjes]

759 houses, 1141 households, circa 6000 inhabitants 
Arhivele Naționale Direcția Județeană Mureș [Regional State Archive in Tirgu Mures, RO]

Tîrgu-Mureş, Str. Crizantemelor, Nr. 8, cod 540073, jud. Mureş

Telefon: 0265/202372, 0265/202371

Fax: 0265/235064

E-mail: mures.an@mai.gov.ro

3/1786 Recensămîntul populaţiei din municipiul Tg. Mureş din anul 1786 vol. I [Population census in the town of Tg. Mureş/Marosvásárhely in 1786, vol I]

Houses 1-100

4/1786, vol. II, houses 101-200

5/1786, vol. III, houses 201-300

6/1786, vol. IV, houses 301-400

7/1786, vol. V, houses 401-500

8/1786, vol. VI, houses 501-600

9/1786, vol. VII, houses 601-700

10/1786, vol. VIII, houses 701-800

11/1786, vol. IX, houses 801-860

Komárom-Esztergom Megyei Levéltár [Archive of county Komárom-Esztergom HU]

www.kemarchiv.hu

2501 Esztergom, Vörösmarty u. 7.

Tel.: +36 33 500-405; +36 33 400-768

fax: +3633 500-406

E-mail: kemarchiv@mail.iif.hu

IV.1.i. Nép-és lélekösszeírások, 1735-1784 [Population censuses, 1732-1784]

Populations Buch über den Orth Neudorf, 1785, 260 sheets [The census of the village of Nyergesújfalu/Neudorf]

\section{Heves Megyei Levéltár [Archive of county Heves, HU]}

www.hevesarchiv.hu

3300 Eger, Mátyás király út 62.

Tel.: +36 36 320-144, +36 36 517-343

Fax: +36 36-517-342

E-mail: hevesarchiv@hevesarchiv.hu

IV.34/1. 951. Népszámlálások 1786-1869 [Population censuses, 1786-1869]

The census of the village Felnémet, 1786, 121 sheets, (117 houses, 129 households)

\section{Bács-Kiskun Megyei Levéltár [Archive of county Bács-Kiskun, HU]}

www.bacs-kiskun-leveltar.hu

6000 Kecskemét, Klapka utca 13-15.

Telefon/Fax: +36 76/495-951, 495-952

E-mail: leveltar@bacs-kiskun-leveltar.hu

V.320. Dunapataj nagyközség iratai [The documents of the village of Dunapataj, in the ancient county of Pest-Pilis-Solt, HU]

$\mathrm{a} / 3 / 45$. The census of Dunapataj in 1785,319 sheets (685 houses, circa half of the sheets remained) 


\section{Conscriptio Popularis Ignobilium, 1804-1847}

The census of the non-noble population was ordered by the central administration. It was carried out year by year between 1804 and 1847. It was an attempt to set up a continuous population register based on annual enumerations. In theory this would provide us with long series of census-like material for every settlement of the kingdom (Transylvania was not the part of the Hungarian kingdom in this period so there this kind of enumeration was not prepared). In fact, we have only fragments of the individual census sheets ("Phylera A"), and so far we have not found longer series either. Although a great amount of summary tables was preserved ("Phylera B" - summaries by house, and "Phylera C" - summaries by settlement) here we list only the remaining individual material.

Data: pre-printed unified sheets were used, all non-noble household members were included, the enumeration was carried out house by house, households were clearly separated, name, year of birth (only in the case of males), 'qualification' (social status/profession in the case of household head, status within the household in the case of other members) indicated, people were classified by pre-printed categories (socio-professional categories, marital status in the case of males aged 16-40, denomination, being absent or foreigner).

\section{Budapest Főváros Levéltára [The Archive of Budapest]}

http://bfl.archivportal.hu/

1139 Budapest, Teve u. 3-5.

Tel: +36 298-7503, +36 298-7504

E-mail: bfl@bparchiv.hu

IV. 1002/s. Buda város Tanácsának iratai, Nem nemesek összeírásai/Conscriptio Popularis Ignobilium, 1804-1830 [The documents of the town of Buda, censuses of the non-noble population]

Boxes $1-30$, census sheets by quarters

1. Vár: $1818,1823,1830$

2. Vár: without year

3. Viziváros summaries: 1805, 1814, 1819, 1823, 1825, without year

4. Viziváros: 1818

5. Viziváros: 1805, without year

6. Viziváros: without year

7. Viziváros: $1824 / 25$

8. Viziváros: 1827

9. Viziváros: 1821,1828

10. Viziváros: 1829

11. Viziváros: 1830

12. Tabán: 1805

13: Tabán: 1815

14. Tabán: 1817

15. Tabán: $1818 / 1$

16. Tabán: $1818 / 2$

17. Tabán: 1819

18. Tabán: 1827

19. Tabán: 1830

20. Tabán without year 
21. Tabán without age

22. Krisztinaváros: $1817,1824,1830$

23. Krisztinaváros: without year

24. Krisztinaváros: without year

25. Országút: without year

26. Újlak: 1804

27. Újlak: without year

28. Újlak: without year

29. Újlak: without year

30. Summaries

Pest Megyei Levéltár, Nagykőrös [Archive of county Pest in Nagykőrös, HU]

www.pestmlev.hu

2750 Nagykőrös, Hősök tere 4.

Telefon: +36 53 350-492

e-mail: postmaster@pmlnagykoros.t-online.hu

V.1/g. Cegléd Mezőváros Tanácsának iratai, Népösszeírások, 1824-1846 [The documents of the town of Cegléd, Population censuses, 1826-1846]

Boxes 1-7

1-5. Conscriptio Popularis Ignobilium, 1824-1828 (from one year, probably 1826) - by alphabetical order of the family names - almost entire (circa 3,000 houses, 15,000 inhab.)

6. I-V. decades (quarters) 1840/41

7. I-V. decades (quarters) 1839/40 - circa half of the town

V.202/e. Nagykőrös város Tanácsának iratai, összeírások 1642-1847 [The documents of the town of Nagykörös, censuses, 1642-1847]

Boxes 1-2 - Conscriptio popularis Ignobilium, 1827 - fragments

Csongrád Megyei Levéltár, Makói Levéltára [Archive of county Csongrád in Makó, HUl

www.csml.hu

6900 Makó, Széchenyi tér 6.

Tel.: +36 62 211-145; mobil: +36 20 435-1843;

e-mail: csmlmako@csml.hu

V.101/e Makó város Tanácsának iratai, Népösszeírási iratok, 1847 [The documents of the town of Makó, population census, 1847]

1-7. Conscriptio Popularis Ignobilium, 1847 - the whole town (circa 5,000 houses, 25,000 inhab.)

Hajdú-Bihar Megyei Levéltár, Hajdúböszörményi Fióklevéltár [Archive of county Hajdú-Bihar in Hajdúböszörmény, HU]

http://hbml.archivportal.hu

Hajdúböszörmény, Dorogi u. 5.

Tel: +36 30-6377-974

e-mail: fiokleveltar@hbml.hu

V.A.402/i Hajdúszoboszló város iratai, lakosok és telkek összeírása, 1839-1846 [The documents of the town of Hajdúszoboszló, census of the inhabitants and land propriety] 
6 volumes

Conscriptio Popularis Ignobilium, 1839-1846 (from one year in this period without exact date, maybe an enumeration from 1839 and the yearly corrections till 1846) I-VI decades (quarters of the town) - not entire

\section{Vas Megyei Levéltár [Archive of county Vas, HU]}

www.vaml.hu

9700 Szombathely, Hefele Menyhért u. 1.

Telefon: +36 94 514-412

Fax: +3694 509-267

E-mail: kutatoszolgalat@mail.vaml.hu

IV.1./j. Népességösszeírások, 1804-1832 [Population censuses, 1804-1832]

2. The census (Conscriptio Popularis Ignobilium) of the village Rábahídvég, 1832 - 123

houses, entire

Győr-Moson-Sopron Megye Soproni Levéltára [Archive of county Győr-Moson-Sopron in Sopron, HU]

http://www.leveltar.sopron.hu/

9400, Sopron, Fö tér 1.

Tel./Fax: +3699312198

e-mail: sopronlt@bparchiv.hu

IV.1./1/aa Sopron vármegye nemesi közgyülésének iratai, conscriptiones populares, 18041836 [The documents of the noble community's assembly of county Sopron, conscriptiones populares, 1804-1836]

Here listed only the villages with individual sheets by year (now partly belonging to Hungary, partly to Austria):

1811

Agyagos 72 houses, Alsó Bük 71, Alsó Pásztori 22, Barbacs 93, Berekallya 21, Beő 117, Bogyoszló 112, Chernelháza 18, Damonya 37, Dör 65, Ebergőc 92, Esterház 51, Felsőbük 52, Felső Pásztori 34, Göbös 6, Hidegség 76, Homok 68, Jobbaháza 91, Keczöl 83, Kisboldogasszony 8, Kiscenk 41, Kis Tata 43, Kövesd 156, Középbük 48, Lócs 40, Loózs 176, Maglócza 37, Mesterháza 24, Muzsaj 39, Nagycenk 142, Nagygeresd 46, Nemesládony 31, Németi 44, Németkeresztúr 18, Pereszteg 121, Pinnye 68, Pórládony 46, Potyond 31, Sajtoskál 46, Sarród 184, Sebes 41, Süttör 115, Szárföld 124, Szécseny 52, Széplak 119, Tóthkeresztúr 98, Újkér 94, Vadosfa 47, Veszkény 81, Vitnyéd 99, Zsebeháza 17

$1819-1824$

Alsó Bük 124, Babat 192, Beleg 33, Berekallya 25, Beő 118, Beősárkány 11, Bogyoszló 24, Csér 36, Chernelháza 20, Damonya 37, Felsőbük 102, Középbük 84, Loózs 72, Mesterháza 38, Mihályi 19, Nagymarton 21, Nemesládony 80, Nemeskér 93, Ossli 90, Páli 16, Pórládony 56, Sajtoskál 52, Szárföld 23, Szill 14, Szováth 13, Tamási 21, Tornyháza 39

1825

Berekallya 25, Kaál 41, Középbük 55, Lózs 48, Nemesládony 27, Pórládony 56, 
Antau 144, Czagersdorf 97, Czemendorf 111, Czillingthal 170, Klimpa 118, Stettera 114, Vulka Pordány 205

1830

Hirm 44, Nagy Höflein 180, Szárazvám 148

1831

Büdöskút 152

1834

Medgyes 170, Vohndorf Brennberg 201

1836

Czinfalva 198

Győr-Moson-Sopron Megye Mosonmagyaróvári Levéltára [Archive of county GyőrMoson-Sopron in Mosonmagyaróvár, Hu]

http://www.gyormegy-arch.hu/

9200 Mosonmagyaróvár, Városház u. 4.

Telefon/Fax: +36 96 215-658

V.2041/623. the village of Moson, Conscriptio popularis Ignobilium, 1842

96 houses, a fragment (a quarter part of the settlement, the total consists of circa 370 houses)

\section{Census 1850-1851}

Population census ordered and carried out by the Austrian government after the revolution of 1848-1849.

Data: pre-printed sheets in German language, in the same form everywhere, name of houseowner, name of each household member, year of birth, rank, office or profession and denomination, marital status and at first time nationality was also recorded, character of stay, presence and absence was indicated at each person while only males were classified according to age groups.

\section{Budapest Főváros Levéltára [The Archive of Budapest]}

http://bfl.archivportal.hu/

1139 Budapest, Teve u. 3-5.

Tel: +36 298-7503, +36 298-7504

E-mail: $\underline{\text { bfl@bparchiv.hu }}$

IV.1106/d. Buda város Tanácsának iratai [The documents of the town of Buda],

Különféle népesség,- ingatlan,- és állatösszeírások [Different population, immovable property and animal censuses]

3. Krisztinaváros, census 1850, 91 sheets (households) (a fragment between house numbers 2-444 - total number of houses: circa 500), Tabán 4 sheets (total: 950 houses)

Census of the domestic animals (Viehstands-Tabelle), 1850, town of Buda (household heads by name and house number, the number of different domestic animals by household) - Vár (Burg) is not entire, Tabán is missing 
Pest Megyei Levéltár, Budapest [Archive of county Pest in Budapest]

www.pestmlev.hu

1097 Budapest, Vágóhíd utca 7.

Telefon: +36 $1455-9050$

Fax: +36 $1455-9053$

e-mail:pestmlev@t-online.hu

V.142/d. Kiskunlacháza mezőváros tanácsának iratai, népesség-összeírás, 1850-1859 [The documents of the town of Kiskunlacháza, population censuses, 1850-1859]

5 volumes - the census 1850 for the market town of Kiskunlacháza (739 houses) and Móriczgát puszta (33 houses - outskirt of the town) - entire with the census of domestic animals and the register of foreigners

V.1095. Pilisborosjenő nagyközség iratai, 1805-1949 [The documents of the village of

Pilisborosjenő]

Bb. Elöljárósági iratok, 1848-1872 [Documents of the leadership of the village]

1. box: census 1850,98 houses with some missing ones - almost entire

Tolna Megyei Levéltár [Archive of county Tolna, HU]

www.tolnalev.hu

7100 Szekszárd, Béla király tér 1.

Tel./fax: +36-74/319-473

e-mail: tolnalev@,c3.hu

IV.B.152/b Tolna megye Császári és Királyi Megyehatóságának iratai, 1850-1871 [Documents of the Imperial/Royal Administration of county Tolna, 1850-1871]

Population census 1850: town of Bonyhád (box 9) 385 sheets - not entire (total is around 500)

\section{Baranya Megyei Levéltár [Archive of county Baranya, HU]}

www.bml.hu

7623 Pécs, Rét u. 9.

Tel.: +36 72 517-350

Fax: +3672 517-358

e-mail: bml@,bml.hu

IV.152./e Baranya Megye Császári és Királyi Megyehatóságának iratai, Népszámlálási iratok, 1850-1857, [Documents of the Imperial/Royal Administration of county Baranya, Population censuses, 1850-1857]

Census 1850: the village of Piskó: 83 houses - entire

The village of Kiscsány: 98 houses - entire

Csongrád Megyei Levéltár, Makói Levéltára [Archive of county Csongrád in Makó, HU]

www.csml.hu

6900 Makó, Széchenyi tér 6.

Tel.: +36 62 211-145; mobil: +36 20 435-1843;

e-mail: csmlmako@csml.hu 
V.A.101/g. Makó város Tanácsának iratai, Népösszeírás az Országos Népszámlálási Küldöttség által, 1850 [The documents of the town of Makó, Population census 1850 by the Commitee of Population census]

Boxes 1-6: 5564 houses, in theory entire, but nowadays the first half of the material is missing (1-2639. houses, not found in the archive but being searched for)

Csongrád Megyei Levéltár, Szentesi Levéltára [Archive of county Csongrád in Szentes, HU]

www.csml.hu

6600 Szentes, Kossuth tér 1.

Tel./fax: +36 63 562-425, 562-426;

e-mail:leveltar@szentes.hu

IV.B.151/e Csongrád megye Császári és Királyi Megyehatóságának iratai, Népszámlálási iratok, 1850-1857, [Documents of the Imperial/Royal Administration of county Csongrád, Population censuses, 1850-1857]

Box 2.

- Census 1850: village of Baks: 79 houses, 136 households, entire with the census of domestic animals and the register of foreigners

- Census 1850: village of Dongér: 61 houses, 100 households, some missing houses

Győr-Moson-Sopron Megye Mosonmagyaróvári Levéltára [Archive of county GyőrMoson-Sopron in Mosonmagyaróvár, Hu]

http://www.gyormegy-arch.hu/

9200 Mosonmagyaróvár, Városház u. 4.

Telefon/Fax: +36 96 215-658

V.B.1601/e. Magyaróvár város Tanácsának iratai, népszámlálási iratok [The documents of the town of Magyaróvár, population censuses, 1850-1869]

Box 1: census sheets from 1850, the town of Magyaróvár, 179 houses, 493 sheets (households) - almost entire

V.B. 2041./580. the village of Moson

Census 1850: 201-371 houses - the first 200 houses are missing

Győr város levéltára [The archive of the town of Győr HU]

www.vleveltar.gyor.hu

9024 Györ, Rákóczi Ferenc u. 1.

Tel: +36 $96312-288$

E-mail: leveltar@enternet.hu.

XV/5. Népösszeírások levéltári gyüjteménye, 1784-1870 [Collection of population censuses] A fragment from the census 1850 (two suburbs):

I. Nádorváros (244 houses)

II. Szabadhegy

Hajdú-Bihar Megyei Levéltár, Hajdúböszörményi Fióklevéltár [Archive of county Hajdú-Bihar in Hajdúböszörmény, HU]

http://hbml.archivportal.hu

Hajdúböszörmény, Dorogi u. 5. 
Tel: +36 30-6377-974

e-mail: fiokleveltar@hbml.hu

V.B.342/e. Hajdúnánás város iratai, népszámlálási iratok, 1850 [The documents of the town of Hajdúnánás, population census, 1850]

11 volumes - entire

V.B.443/f. Hajdúszoboszló város iratai, népszámlálási iratok, 1850 [The documents of the town of Hajdúszoboszló, population census, 1850]

10 boxes - entire

Szabolcs-Szatmár-Bereg Megyei Levéltár [Archive of county Szabolcs-Szatmár-Bereg, HU]

www.szabarchiv.hu

4400 Nyíregyháza, Széchenyi u. 4.

Telefon/fax: +36 42/414-313, 42/311-280

E-mail: leveltar@szabarchiv.hu

V. B. 52/f. Nyíregyháza községtanácsának iratai, összeírások, 1850-54 [Documents of the Municipality of the town of Nyíregyháza, censuses, 150-1854]

Census 1850 of Nyíregyháza: 2 volumes

Arhivele Naționale Direcția Județeană Mureș [Regional State Archive in Tîrgu Mureş, RO]

Tîrgu-Mureş, Str. Crizantemelor, Nr. 8, cod 540073, jud. Mureş

Telefon: $0265 / 202372,0265 / 202371$

Fax: 0265/235064

E-mail: mures.an@mai.gov.ro

34/1850 - 45/1850 Recensămîntul populației din municipiul Tg. Mureş din anul 1850 vol. I [Population census in the town of Tg. Mureş/Marosvásárhely in 1850]

14 volumes: 1349 houses - entire

Arhivele Naționale Direcția Județeană, Satu Mare [Regional State Archive in Satu Mare, RO]

Satu Mare, str. 1 Decembrie 1918 nr. 13, cod 44001, jud. Satu Mare

Telefon: 0261/711102

Fax: 0261/711102

E-mail: satumare.an@mai.gov.ro

Fond: Primăria municipiului Satu Mare [The documents of the mayor's office in Satu Mare/Szatmárnémeti]

Census 1850 in Satu Mare/Szatmárnémeti, RO

Archív mesta Košice [Archive of the town of Košice/Kassa, SLO]

Kováčska 20, 04001 Košice

Tel.: 6221825

E-mail: archiv@ archiv.kosice.sk 
AMK DO 1850: Archív Mesta Košice, Zbierky, Súpisy domov, Obyvat'elov, 1850.

Census 1850 in the town of Košice/Kassa - almost entire, foreigners are missing, population de jure 9858 inhabitants (total is 10185, according to the summary)

\section{Census 1857}

Census sheet is very similar to that of 1850 with smaller differences: nationality was omitted, an exact date of birth was demanded, prescribed categories were used for the classification by profession, the representatives of both sexes were put into age categories but females had less and broader age-groups than males. Two types of sheets survived: the original ones (Aufnahmsbogen), and the preliminary registration sheets in the towns on which the houseowners could register the inhabitants (Anzeigezettel) and on the basis of which the census sheets were prepared. The latter ones contain the same information but profession was written down freely and the given person was classified later on the census sheet according to preprinted categories based on the information of Anzeigezettel. Beside this, Anzeigezettel indicated the number of domestic animals while Aufnahmsbogen didn't, about them separate sheet was prepared similarly to residing foreigners.

The surviving material is significant, therefore we continue the presentation archive by archive, but the list of settlement will be presented in the attached excel files by administrative units (counties) of the period.

\section{a) Towns}

\section{Budapest Főváros Levéltára [The Archive of Budapest]}

http://bfl.archivportal.hu/

1139 Budapest, Teve u. 3-5.

Tel: +36 298-7503, +36 298-7504

E-mail: bfl@,bparchiv.hu

IV.1106./e. Buda város Tanácsának iratai, 1848-1873, Népösszeírási felvételi ívek, 1857 [The documents of Buda's senate, 1848-1873, census sheets from 1857 by quarters with lacks] boxes $1-14$

1. Vár (Burg) houses $1-180$

2. Vár (burg) houses $181-218$

3. Wasserstadt houses $201-400$

4. Wasserstadt houses 401-600

5. Wasserstadt houses 601-761

6. Landstrasse houses 201-307

7. Tabán houses 501-700

8. Tabán houses 701-932

9. Neustift houses 1-180

10. Neustift houses 181-383

11. Christinastadt houses $1-260$

12 Christinastadt houses 261-345

13. Mixed

14. Mixed

Győr város levéltára [The archive of the town of Győr HU] 
www.vleveltar.gyor.hu

9024 Győr, Rákóczi Ferenc u. 1.

Tel: +36 96 312-288

E-mail: leveltar@enternet.hu.

XV/5. Népösszeírások levéltári gyüjteménye, 1784-1870 [Collection of population censuses]

Data of the census 1857 in Györ- entire

I. Szabadhegy (1-187 houses)

II. Innern Stadt (1-300 houses)

III. Innern Stadt (301-555 houses)

IV. Ferdinandstadt (1-39 houses)

V. Franzstadt (1-36 houses)

VI. Wiener Vorstadt (1-300)

VII. Wiener Vorstadt (301-565)

VIII. Palatin Vorstadt (1-264 houses)

IX. Freistadt (1-22 houses)

X. Helységi átnézetek mindegyik városrészre (Summaries by quarters)

XI. Bejelentési jegyek (marhaszám, foglalkozás stb.) mindegyik háztartásra (domestic

animals, summaries by profession, by household)

Győr-Moson-Sopron Megye Mosonmagyaróvári Levéltára [Archive of county GyőrMoson-Sopron in Mosonmagyaróvár, Hu]

http://www.gyormegy-arch.hu/

9200 Mosonmagyaróvár, Városház u. 4.

Telefon/Fax: +36 96 215-658

V.B.1601/e. Magyaróvár város Tanácsának iratai, népszámlálási iratok [The documents of the town of Magyaróvár, population censuses, 1850-1869]

Box 2 the census 1857 in Magyaróvár (Anzeigezetteln) 243 houses, 647 household, 3360

inhab. - entire

Pest Megyei Levéltár, Nagykőrös [Archive of county Pest in Nagykőrös, HU]

www.pestmlev.hu

2750 Nagykőrös, Hősök tere 4.

Telefon: +36 53 350-492

e-mail: postmaster@pmlnagykoros.t-online.hu

V.42. Cegléd város Tanácsának iratai 1848-1871 [The documents of Cegléd town's senate]

f. Összeírások 1853-1862. [Censuses]

Boxes 1-5 Population census 1857 in Cegléd - entire

Anzeigezetteln

1. 1-900 houses

2. 901-1800 houses

3. 1801-2700 houses

4. 2701-3700 houses

5. 3700-4207 houses

Bács-Kiskun Megyei Levéltár [Archive of county Bács-Kiskun, HU]

www.bacs-kiskun-leveltar.hu

6000 Kecskemét, Klapka utca 13-15. 
Telefon/Fax: +36 76/495-951, 495-952

E-mail: leveltar@bacs-kiskun-leveltar.hu

IV/1609/1 Kecskemét város tanácsának iratai, Népszámlálási iratok 1857, [The documents of Kecskemét town's senate, Population census, 1857]

Census 1857 in Kecskemét by quarters (decades) with significant lacks - circa one tenth part of the total material remained

3 boxes

1. houses $1-355$ (decade 5$)$

2. houses $254-576$ (decade 2 ) houses 313-430 (decade 8)

3. houses $431-576$ (decade 8 )

Téglások: houses 2-99

Bács-Kiskun Megyei Levéltár, Bajai részleg [Archive of county Bács-Kiskun in Baja, HU]

$\underline{\text { www.bacs-kiskun-leveltar.hu }}$

6500 Baja, Bajcsy-Zsilinszky utca 12-14.

Telefon/Fax: +36 79/523-900/307

E-mail: leveltar@bacs-kiskun-leveltar.hu

IV.1105./g. Baja Város Tanácsának iratai, Népszámlálási iratok (1857) [The documents of Baja town's senate, Population census (1857)]

Census 1857 in Baja, 4 boxes by quarters, entire, circa 2500 houses

Székesfehérvár város levéltára [Archive of the town of Székesfehérvár, HU]

www.albaarchiv.hu

8000 Székesfehérvár, Zichy liget 10.

Tel.: +3622502 252

E-mail: albaarchivum@enternet.hu

IV. 1107. Székesfehérvár város Tanácsának iratai [The documents of Székesfehérvár town’s senate]

c) Népszámlálási iratok $(1850,1857,1869)$ [Censuses 1850, 1857, 1869]

Census 1857 in Székesfehérvár by quarters, almost entire (circa 2500 houses)

Csongrád megyei Levéltár, Szeged [Archive of county Csongrád in Szeged, HU]

www.csml.hu

6720 Szeged, Dóm tér 1-2.

Tel./fax: +36 62 425-199; mobil: +36 20 347-3060;

e-mail:csml@csml.hu

IV.B.170. Csanád megye 1857. évi népszámlálási és állatösszeírási iratai. [Population census and register of domestic animals in county Csanád in 1857]

The census sheets of the town of Makó, 3466 houses + hamlets and outskirts - almost entire

Csongrád Megyei Levéltár, Szentesi Levéltára [Archive of county Csongrád in Szentes, HUl 
$\underline{\text { www.csml.hu }}$

6600 Szentes, Kossuth tér 1.

Tel./fax: +36 63 562-425, 562-426;

e-mail:leveltar@szentes.hu

V.B.145/h. Szentes város tanácsának iratai, Népösszeírások, 1850-1870 [The documents of Szentes town's senate, Population censuses, 1850-1870]

Boxes 2-11. Census 1857 in Szentes, (Anzeigezetteln) 4290 houses - entire

2. 1-200. ház

3. $201-600$

4. $601-1000$

5. $1001-1400$

6. $1401-1700$

7. $1701-2000$

8. $2001-2300$

9. $2301-2700$

10. $2701-3500$

11. 3501-4290. houses

Csongrád Megyei Levéltár, Csongrád [Archive of county Csongrád in Csongrád] $\underline{\text { www.csml.hu }}$ 6640 Csongrád, Gyöngyvirág u. 7/a

Tel.: +36 63 570-005, mobil: +36 20 341-0797

e-mail: csml@csongrad.hu

V.B.42./f. Csongrád város tanácsának iratai, Népösszeírási iratok, 1857. [Documents of Csongrád town's senate, Census documents, 1857]

A fragment: 1 box - circa 300-400 houses from 1400

Jász-Nagykun-Szolnok Megyei Levéltár [Archive of county Jász-Nagykun-Szolnok, HU] www.szolarchiv.hu

5000 Szolnok, Pozsonyi u. 40-42.

Telefon: +36 56/421-404, +36 56/344-161

Fax: +36 56/421-404

E-mail cím: leveltar@szolarchiv.hu

V.500. Túrkeve város levéltára, Népszámlálási ívek, 1857 [Archive of the town of Túrkeve, Population census, 1857]

Census, 1857 in Túrkeve

Houses 26-735; 736-1418; 1419-1999 - almost entire

Békés Megyei Levéltár [Archive of county Békés, HU]

www.bekes-archiv.hu

5700 Gyula, Petőfi tér 2.

tel.: +36 $20289-8909$

e-mail: leveltar@,bekes-archiv.hu

IV. B. 152. A Békés-Csanádi Cs. Kir. Megyehatóság iratai [Documents of Békés county’s Imperial/Royal administration] 
b/ 309. box

Census 1857 in Békéscsaba, a fragment (208 households, total is around 6500)

Hajdú-Bihar Megyei Levéltár, Hajdúböszörményi Fióklevéltár [Archive of county Hajdú-Bihar in Hajdúböszörmény, HU]

http://hbml.archivportal.hu

Hajdúböszörmény, Dorogi u. 5.

Tel: +36 30-6377-974

e-mail: fiokleveltar@,hbml.hu

V. B. 142/e. Hajdúdorog város iratai, népösszeírási felvételi ívek 1857. 1 kötet [The documents of the town of Hajdúdorog, population census 18571 volume]

Not entire

Archivele Naționale, Direcția Județeană Brasov [Regional State Archive in Brasov, RO] Str. Gh. Barițiu 34, Braşov, cod 500025, jud. Braşov

Telefon: 0268/475256

Fax: 0268/478742

E-mail: brasov.an@mai.gov.ro

Primaria orasului Brasov

Seria acte: Recensamantul populatiei din Brasov si Tara Barsei

Inventarul documentelor din anii 1526-1917 [The documents of the mayor's office in Brasov, Population censuses, 1526-1917]

Fond nr. 1.

Inventar nr: 9.

Pach. XIV.

Fragment of the census 1857 in Brasov/Brassó

Houses $599-700 ; 792-800 ; 826-835$ (total is more than 3000 houses)

Archivele Naționale, Direcția Județeană Maramures [Regional State Archive, Maramures, RO]

B-dul Bucuresti nr. 26, Baia Mare, jud. Maramureş

Telefon: 0262/437948

E-mail: maramures.an@mai.gov.ro

Fond: Primăria Oraşului Baia Mare [The documents of the mayor's office in Baia

Mare/Nagybánya]

Inventar nr.: 370.

Dosar nr.: 37-44/1857.

Original Sheets of the census 1857

Houses 1-799 (entire) + outskirts of Nagybánya (Valea Neagra: 22 houses, Blidarra: 73

houses, Ulmoasara: 25 houses).

Arhivele Naționale Direcția Județeană, Satu Mare [Regional State Archive in Satu Mare, RO]

Satu Mare, str. 1 Decembrie 1918 nr. 13, cod 44001, jud. Satu Mare

Telefon: 0261/711102

Fax: 0261/711102

E-mail: satumare.an@mai.gov.ro 
Fond: Primăria municipiului Satu Mare [The documents of the mayor's office in Satu Mare/Szatmárnémeti]

Census 1857 in Satu Mare/Szatmárnémeti, RO

Arhivele Naționale Direcția Județeană Mureș [Regional State Archive in Tîrgu Mureş, RO]

Tîrgu-Mureş, Str. Crizantemelor, Nr. 8, cod 540073, jud. Mureş

Telefon: $0265 / 202372,0265 / 202371$

Fax: 0265/235064

E-mail: mures.an@mai.gov.ro

Recensămîntul populației din municipiul Tg. Mureş din anul 1857 [population census 1857 in Tg. Mureş/Marosvásárhely]

46/1857-60/1857, the census 1857 of the town of Marosvásárhely, 1466 houses - entire

b) Villages

Arhivele Naționale Direcția Județeană Mureș [Regional State Archive in Tîrgu Mureş, RO]

Tîrgu-Mureş, Str. Crizantemelor, Nr. 8, cod 540073, jud. Mureş

Telefon: 0265/202372, 0265/202371

Fax: 0265/235064

E-mail: mures.an@mai.gov.ro

Fond nr. 30. Colecția Recensămintele Populației pe anii 1857-1870 [Population census in 1857]

Inventar nr. 137

Census 1857 in county Maros, RO

165 villages, all in Romania

Štátny archív v Košiciach [State Regional Archiv in Košice/Kassa, SLO]

http://www.civil.gov.sk/snarchiv

Bačíkova 1, 04156 Košice, Slovakia

Telephone: 421 (0) 556222415

Fax: 421 (0) 55729 3245, 421 (0) 556220840

E-mail: archiv@sake.vs.sk

Šoba KE, ATŽ Sčítanie L’udu v r. 1857 [Population census 1857 in county Abaúj-Torna]

Census 1857, county Abaúj-Torna, 257 villages: at present 123 villages in Slovakia, 134 villages in Hungary

Štátny oblastný archív, Prešov [Regional State Archive in Prešov/Eperjes, SLO]

Slanská 31, 08006 Prešov - Nižná Šebastová

Tel.: 091-7460052 - ústredňa, 091-7460055 - bádatel’ňa

Fax: 091-7764059

E-mail: archiv@sapo.vs.sk

Šarišká župa, súpisy obyvatelstva, 1780-1870 
5. Sčítanie obyvatelstva Šž z r. 1857

Sčítacie hárky, 1857 [Population census sheets in county Sáros/Šariš, 1857]

379 villages in the historic county Sáros, Slovakia

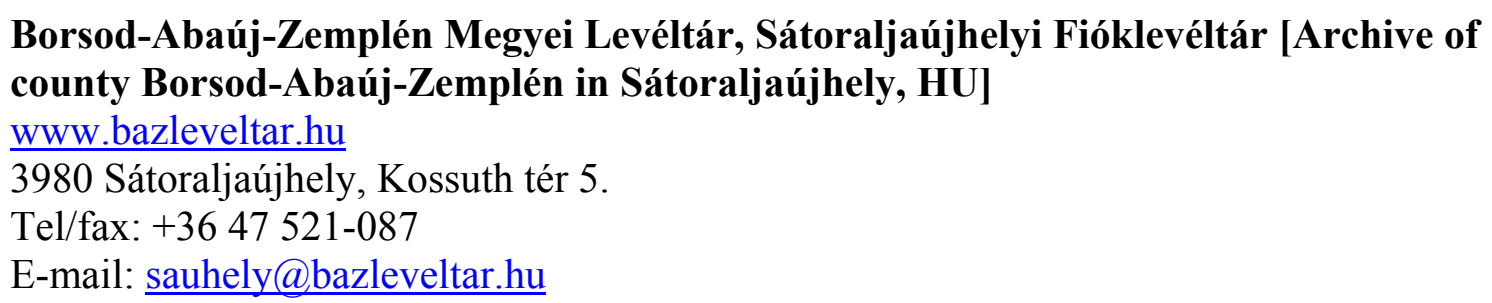

XV./82. Zemplén vármegyei 1857. évi népszámlálási iratok gyüjteménye [Collection of population census from 1857 in county Zemplén]

17 villages from county Zemplén, at present 16 in Slovakia, 1 in Hungary

\section{Nógrád Megyei Levéltár [Archive of county Nógrád, HU]}

www.nogradarchiv.hu

3100 Salgótarján, Bem út 18.

Telefon/Fax: +36 32/412-801, +36 32/310-043

e-mail: starjan@nogradarchiv.hu

IV.152. A Nógrádi Cs. Kir. Megyehatóság (neograder k. k. Komitatsbehörde) iratai 18501860 [Documents of Nógrád county's Imperial/Royal administration] e. Az 1857. évi népszámlálás felvételi lapjai [Census sheets from 1857] 54 villages from the historic county Nógrád (1857), at present all in Slovakia

Győr-Moson-Sopron Megye Soproni Levéltára [Archive of county Győr-Moson-Sopron in Sopron, HU]

http://www.leveltar.sopron.hu/

9400, Sopron, Fö tér 1.

Tel./Fax: +36 99312198

e-mail: sopronlt@,bparchiv.hu

IV.B.158/e. Az 1857-es népszámlálás iratai [Documents of the census 1857]

67 villages, one part of historic county Sopron, at present 16 villages in Hungary, 51 in

Austria

Tolna Megyei Levéltár [Archive of county Tolna, HU]

www.tolnalev.hu

7100 Szekszárd, Béla király tér 1.

Tel./fax: +36-74/319-473

e-mail: tolnalev@.c3.hu

IV.B.152/b Tolna megye Császári és Királyi Megyehatóságának iratai, 1850-1871

[Documents of the Imperial/Royal Administration of county Tolna, 1850-1871]

Population census in county Tolna, 1857

8 villages + outskirts and fragments - all in Hungary

+ Bonyhád market town - 559 houses + outskirts - entire 
Csongrád megyei Levéltár, Szeged [Archive of county Csongrád in Szeged, HU]

$\underline{\text { www.csml.hu }}$

6720 Szeged, Dóm tér 1-2.

Tel./fax: +36 62 425-199; mobil: +36 20 347-3060;

e-mail:csml@,csml.hu

IV.B.170. Csanád megye 1857. évi népszámlálási és állatösszeírási iratai. [Population census and register of domestic animals in county Csanád in 1857]

32 settlements from the historic county Csanád (villages, hamlets and the town of Makó most of them in Hungary)

Csongrád Megyei Levéltár, Szentesi Levéltára [Archive of county Csongrád in Szentes, HU]

www.csml.hu

6600 Szentes, Kossuth tér 1.

Tel./fax: +36 63 562-425, 562-426;

e-mail: leveltar@szentes.hu

IV.B.151/e Csongrád megye Császári és Királyi Megyehatóságának iratai, Népszámlálási iratok, 1850-1857, [Documents of the Imperial/Royal Administration of county Csongrád, Population censuses, 1850-1857]

Bunches 4-5: census sheets of villages Mindszent and Tömörkény (1302 sheets) - entire

Komárom-Esztergom Megyei Levéltár [Archive of county Komárom-Esztergom HU] www.kemarchiv.hu

2501 Esztergom, Vörösmarty u. 7.

Tel.: +36 33 500-405; +36 33 400-768

fax: +3633 500-406

E-mail: kemarchiv@mail.iif.hu

IV.B.153/B. Esztergom megyei Császári-Királyi Megyehatóság iratai, 1857. évi népösszeírás [Documents of the Imperial/Royal Administration of county Esztergom, Population census in 1857]

Original census sheets of 11 villages (from 21 from which census material has remained), of which only 5 is more or less entire: 3 in Hungary, 2 in Slovakia at present

Jász-Nagykun-Szolnok Megyei Levéltár [Archive of county Jász-Nagykun-Szolnok, HU] www.szolarchiv.hu

5000 Szolnok, Pozsonyi u. 40-42.

Telefon: +36 56/421-404, +36 56/344-161

Fax: +36 56/421-404

E-mail cím: leveltar@,szolarchiv.hu

V.1400.186-187. Jászkisér község levéltára, Népszámlálási ívek, 1857 [the Archive of Jászkisér village, census sheets, 1857]

1000 sheets - almost entire 
Pest Megyei Levéltár, Budapest [Archive of county Pest in Budapest]

www.pestmlev.hu

1097 Budapest, Vágóhíd utca 7.

Telefon: +36 1 455-9050

Fax: +36 $1455-9053$

e-mail: pestmlev@,t-online.hu

V.1095. Pilisborosjenő nagyközség iratai, 1805-1949 [The documents of the village of Pilisborosjenő]

Bb. Elöljárósági iratok, 1848-1872 [Documents of the leadership of the village]

A fragment from 1857 - 33 houses (form circa 100)

Directia Judeteana Sibiu a Arhivelor Nationale [Regional State Archive in Sibiu, RO]

Sibiu, Str. Arhivelor nr.3, cod 550164, jud. Sibiu

Telefon: $0269 / 431356$

E-mail: sibiu.an@mai.gov.ro

Inventar 74. Colectia de tabele cu contributii ale comunelor 1754-1830 (a községek adózási iratanyagai) [Tax documents]

Actele apartinatoare comunei Cisnadie (Nagydisznód - németül Heltau - településre vonatkozó levéltári anyagok) [Documents of Nagydisznód/Cisnadie/Heltau]

Nr. 68: Statistica populatiei pe anul 1857: nr. 1-300 (népességstatisztika az 1857. évre: 1-300

házszámok, szászok által lakott házak) [houses 1-300, inhabited by Saxons]

Nr. 69: Statistica populatiei pe anul 1857: nr. 301-577 (népességstatisztika az 1857. évre: 301577 házszámok, szászok által lakott házak) [houses 301-577 inhabited by Saxons]

Nr. 70: Statistica populatiei pe anul 1857: nr: 1-43 (népességstatisztika az 1857. évre: 1-43, románok által lakott házak) [houses 1-43 inhabited by Romanians]

The census sheets of Nagydisznód/Cisnadie/Heltau - entire

Zala Megyei Levéltár (Archive of county Zala, HU)

www.zml.hu

8900 Zalaegerszeg, Széchenyi tér 3.

Telefon: +36 92/510-030, 598-956, 598-957

Telefax: +36 92/510-029

E-mail: zalalev@dfmk.hu

IV.151. Zala Megye Császári és Királyi Megyehatóság iratai [Documents of the Imperial/Royal Administration of county Zala]

Census sheets of two villages: Csapi (62 sheets) and Újlak (112 sheets) - entire

Veszprém Megyei Levéltár [Archive of county Veszprém, HU]

www.veml.hu

8200 Veszprém, Török Ignác u. 1.

Telefon: +36 88 887-200

Fax: +36 88 887-206

E-mail: leveltar@veml.hu 
IV.B.155/c. A Veszprémi Császári és Királyi Megyehatóság iratai, összeírások [Documents of the Imperial/Royal Administration of county Veszprém, censuses]

Census sheets of the village Pápakovácsi ( 86 sheets + domestic animals by household)

Győr-Moson-Sopron Megye Mosonmagyaróvári Levéltára [Archive of county GyőrMoson-Sopron in Mosonmagyaróvár, Hu]

http://www.gyormegy-arch.hu/

9200 Mosonmagyaróvár, Városház u. 4.

Telefon/Fax: +36 $96215-658$

V.2041. Archive of village Moson,

Census sheets from 1857, (Anzeigezetteln), houses 2-200 - not entire (total number of houses in 1850: 371 )

\section{Census 1869}

It was the first census organised by the independent Hungarian Statistical Office. The census sheets consisted of three parts, on the first page the data of the apartment were recorded, second and third one contained the data of the households, while the fourth one showed in detail the number of domestic animals by household. Household register indicated the name of household members, rank, sex, denomination, profession or the character of employment/profession, place of birth, status (resident or foreigner), presence and absence (longer or not than 1 month), literacy were also recorded, in the column of remarks notes could be made on physical disability, military service, place of residence in case of foreigners, place of stay in case of absent persons.

\section{a) Towns}

\section{Hajdú-Bihar Megyei Levéltár [Archive of county Hajdú-Bihar, HU]}

http://hbmleveltar.hu.

4024 Debrecen, Vármegyeház utca 1/B

Tel.: +36 52 507-550/642

fax: $+3652507-550 / 638$

E-mail: leveltar@hbml.hu

IV.A.1109/p. Debrecen város iratai, népszámlálási iratok, 1850-1870 [The documents of the town of Debrecen, population crnsuses, 1850-1870]

22 boxes - the census of Debrecen, 3755 houses in the centre, with outskirts and hamlets more than 5000, 46111 inhabitants - entire

Jász-Nagykun-Szolnok Megyei Levéltár [Archive of county Jász-Nagykun-Szolnok, HU] www.szolarchiv.hu

5000 Szolnok, Pozsonyi u. 40-42.

Telefon: +36 56/421-404, +36 56/344-161

Fax: +36 56/421-404

E-mail cím: leveltar@,szolarchiv.hu 
V.500. Túrkeve város levéltára, Népszámlálási ívek, 1869 [Archive of the town of Túrkeve, Population census, 1869]

Census, 1869 in Túrkeve, 10 boxes more than 2000 houses, in alphabetic order of family

names - entire

\section{Csongrád Megyei Levéltár, Szentesi Levéltára [Archive of county Csongrád in Szentes,}

\section{HU]}

www.csml.hu

6600 Szentes, Kossuth tér 1.

Tel./fax: +36 63 562-425, 562-426;

e-mail:leveltar@szentes.hu

V.B.145/h. Szentes város tanácsának iratai, Népösszeírások, 1850-1870 [The documents of Szentes town's senate, Population censuses, 1850-1870]

Boxes 12-25: the census of Szentes, 1869, entire -4286 houses + houses without number

\section{Bács-Kiskun Megyei Levéltár [Archive of county Bács-Kiskun, HU]}

www.bacs-kiskun-leveltar.hu

6000 Kecskemét, Klapka utca 13-15.

Telefon/Fax: +36 76/495-951, 495-952

E-mail: leveltar@bacs-kiskun-leveltar.hu

IV/1609/1 Kecskemét város tanácsának iratai, Népszámlálási iratok 1869, [The documents of Kecskemét town's senate, Population census, 1869]

The census of the town of Kecskemét (in the historic county Pest-Pilis-Solt), a fragment: 880 houses from the centre (districts 3,4,9) and around 680 houses from the outskirts (total number of houses is 6850)

\section{Székesfehérvár város levéltára [Archive of the town of Székesfehérvár, HU]}

www.albaarchiv.hu

8000 Székesfehérvár, Zichy liget 10.

Tel.: +3622502 252

E-mail: albaarchivum@enternet.hu

IV. 1107. Székesfehérvár város Tanácsának iratai [The documents of Székesfehérvár town's senate]

c) Népszámlálási iratok $(1850,1857,1869)$ [Censuses 1850, 1857, 1869]

Population census in Székesfehérvár in 1869, by district, circa 1700 houses, not entire (total number of houses is 2937)

\section{Győr város levéltára [The archive of the town of Győr HU]}

www.vleveltar.gyor.hu

9024 Győr, Rákóczi Ferenc u. 1.

Tel: +36 $96312-288$

E-mail: leveltar@enternet.hu.

XV/5. Népösszeírások levéltári gyüjteménye, 1784-1870 [Collection of population censuses] 
Data of the census 1869 in Györ - not entire (with smaller lacks - total number of houses is $1823,20,000$ inhabitants)

Győr-Moson-Sopron Megye Mosonmagyaróvári Levéltára [Archive of county GyőrMoson-Sopron in Mosonmagyaróvár, Hu]

http://www.gyormegy-arch.hu/

9200 Mosonmagyaróvár, Városház u. 4.

Telefon/Fax: +36 96 215-658

V.B.1601/e. Magyaróvár város Tanácsának iratai, népszámlálási iratok [The documents of the town of Magyaróvár, population censuses, 1850-1869]

Box 6 - the census sheets of the town of Magyaróvár from 1869

Not entire - data of 152 houses (total number of houses is 260)

Borsod-Abaúj-Zemplén Megyei Levéltár, Miskolc [Archive of county Borsod-AbaújZemplén in Miskolc, HU]

www.bazleveltar.hu

3525 Miskolc, Fazekas út 2.

Tel.: +36 46344885

Fax: +3646344699

E-mail: info@bazleveltar.hu

IV.1925/a. Census sheets from the town of Miskolc, 1869

A fragment, two streets of the town

Archivele Naționale, Direcția Județeană Brasov [Regional State Archive in Brasov, RO] Str. Gh. Barițiu 34, Braşov, cod 500025, jud. Braşov

Telefon: 0268/475256

Fax: 0268/478742

E-mail: brasov.an@mai.gov.ro

Primaria orasului Brasov

Seria acte: Recensamantul populatiei din Brasov si Tara Barsei

Inventarul documentelor din anii 1526-1917 [The documents of the mayor's office in Brasov, Population censuses, 1526-1917]

Fond nr. 1.

Inventar nr: 9.

Pach XVI-XXIV. Census of Brasov/Brassó in 1869, 3477 houses, (total is 3792), almost entire

\author{
Arhivele Naționale Direcția Județeană Mureş [Regional State Archive in Tîrgu Mureş, \\ RO] \\ Tîrgu-Mureş, Str. Crizantemelor, Nr. 8, cod 540073, jud. Mureş \\ Telefon: 0265/202372, 0265/202371 \\ Fax: 0265/235064 \\ E-mail: mures.an@mai.gov.ro
}

Recensămîntul populației din oreşul Tg. Mureş din anul 1869 [population census 1869 in Tg. Mureş/Marosvásárhely] 
61/1869 - 67/1869 population census in Marosvásárhely in 1869, houses 1-1516, entire

\section{b) Villages}

Štátny archív v Košiciach [State Regional Archiv in Košice/Kassa, SLO]

http://www.civil.gov.sk/snarchiv

Bačíkova 1, 04156 Košice, Slovakia

Telephone: $421(0) 556222415$

Fax: 421 (0) 55729 3245, 421 (0) 556220840

E-mail: archiv@sake.vs.sk

Šoba KE, AŽ Sčítanie L’udu v r. 1869 [Population census 1869 in county Abaúj]

The census sheets of 9 villages from the territory of present Slovakia, entire list of villages in the attached excel file with population size and denominational distribution (Abaúj_1869)

Šoba KE, TŽ Sčítanie L'udu v r. 1869 [population census 1869 in county Torna, in 1857 together with county Abaúj]

35 villages of which 20 in present day Hungary, 15 in Slovakia,

\section{Štátny oblastný archív v Nitre [State Regional Archive in Nitra, SLO]}

Novozámocká 273

95112 Ivanka pri Nitre

Telefón: 087/56 42 63, 087/56 4384

Fax: 087/56 4268

Sčítacie hárky v r. 1869, Tekovská župa [Population census of historic county Bars in 1869] 212 villages, all in Slovakia,

Sčítacie hárky v r. 1869, Nitrianska župa [Population census of historic county Nyitra in 1869]

494 villages, all in Slovakia,

Sčítacie hárky v r. 1869, Komárňanská župa [Population census of historic county Komárom in 1869]

45 villages in present-day Hungary, 58 villages in Slovakia,

Békés Megyei Levéltár [Archive of county Békés, HU]

www.bekes-archiv.hu

5700 Gyula, Petőfi tér 2.

tel.: +36 $20289-8909$

e-mail: leveltar@,bekes-archiv.hu

V. 326. Mezöberény nagyközség iratai, [The documents of the village Mezöberény]

B-d 5-7. boxes: census sheets of Mezőberény from 1869, fragments (total is around 11,000 inhabitants and 2,224 houses)

Direcția Județeană Bistrita-Nasaud a Arhivelor Naționale [Regional State Archive in Bistriţa, RO]

Bistrița, Str. Gării nr.3-5, jud. Bistrița-Năsăud 
Telefon: 0263/203249, 0263/203293, 0263/203294

Fax: 0263/203249

E-mail: bistrita.an@mai.gov.ro

Fond: Primaria Orasului Nasaud

Registru inventar nr. 5/1870 Population census in 1869 in 5 settlements, all in Transylvania, Romania, list is in the attached excel file (Beszterce_Naszód_1869)

The census of Nasaud/Naszód (428 houses, 777 households, 2447 inhabitants) has been published:

Bolovan, Ioan - Onofreiu, Adrian - Rus, Viorel: Familiile din Năsăud în anul 1869. Contribuții de demografie istorică. Cluj-Napoca: Argonaut, 2010.

Komárom-Esztergom Megyei Levéltár [Archive of county Komárom-Esztergom HU] www.kemarchiv.hu 2501 Esztergom, Vörösmarty u. 7.

Tel.: +36 33 500-405; +36 33 400-768

fax: $+3633500-406$

E-mail: kemarchiv@mail.iif.hu

IV.253.b. 1869. évi népsség- és háziállatösszeírások [Censuses of population and domestic animals in 1869] - microfilm 175

Census sheets of 8 villages of which 5 in Hungary, 3 in Slovakia are situated,

Direcția Județeană Covasna a Arhivelor Naționale [Regional State Archive of county Covasna, RO]

Sf. Gheorghe, b-dul Gen. Grigore Bălan nr. 12, cod 520013, jud. Covasna

Telefon: 0267/310645, 0267/300407/ 2311

Fax: 0267/310645

E-mail: covasna.an@mai.gov.ro

Fond nr. 8. Scaunul Trei Scaune, Recensamantul populatiei pe anul 1869 [Population census of the historic county Háromszék in Transylvania in 1869]

6 villages of which 5 seem to be entire, all in Romania,

Direcția Județeană Salaj a Arhivelor Naționale [Regional State Archive of county Salaj in Zalău, RO]

Str. Tudor Vladimirescu nr. 26/A, Zalău, cod 450067, jud. Sălaj

Telefon: 0260/611016

E-mail: salaj.an@mai.gov.ro

57 dosare, 41 comune, zona Cehul Silvaniei si jurul Zalaului [the census sheets of 41 settlements in 57 bunches from the region of Cehul Silvaniei in county Zalau]

39 villages with more or less entire material from the historic county Szilágy, - all in

Romania

Arhivele Naționale Direcția Județeană Mureş [Regional State Archive in Tîrgu Mureş, RO]

Tîrgu-Mureş, Str. Crizantemelor, Nr. 8, cod 540073, jud. Mureş

Telefon: 0265/202372, 0265/202371

Fax: 0265/235064 
E-mail: mures.an@mai.gov.ro

Fond nr. 30. Colecția Recensămintele Populației pe anii 1857-1870 [Collection of the population censuses 1857-1870]

Inventar nr. 137

The census sheets of 100 villages in the historic county Maros-Torda, - all in Romania

Bács-Kiskun Megyei Levéltár [Archive of county Bács-Kiskun, HU]

www.bacs-kiskun-leveltar.hu

6000 Kecskemét, Klapka utca 13-15.

Telefon/Fax: +36 76/495-951, 495-952

E-mail: leveltar@bacs-kiskun-leveltar.hu

V.355. Kunszentmiklós nagyközség iratai (1873-ig mezőváros) [The documents of Kunszentmiklós, before 1873 market town]

6/8. Népszámlálási felvételi ívek, 1869 [Census sheets from 1869]

Kunszentmiklós: houses 201-299, 301-400, 901-1000

7/1. Kunszentmiklós: houses 1001-1225

Altogether around 525 houses - not entire (total number of houses: 1223, population: 5593)

on the territory of historic county Pest-Pilis-Solt-Kiskun, Hungary

7/2. Kerekegyháza: houses 75-98, 23 houses from 98 - a fragment

7/3. Orgovány puszta (the outskirt of Kunszentmiklós): 147 houses - entire

Pest Megyei Levéltár, Budapest [Archive of county Pest in Budapest]

www.pestmlev.hu

1097 Budapest, Vágóhíd utca 7.

Telefon: +36 $1455-9050$

Fax: +36 1455-9053

e-mail: pestmlev@t-online.hu

V.142.e. Kiskunlacháza Mezőváros Tanácsának iratai, Közigazgatási iratok, 1869. évi népszámlálás [Documents of the market town of Kiskunlacháza, administrative documents, population census in 1869]

2 boxes: the census sheets of Kiskunlacháza with smaller lacks: 736 houses from 831

In the historic county Pest-Pilis-Solt-Kiskun

Štátny oblastný archív v Bratislave [Regional State Archive in Bratislava, SLO]

Križková 781104 Bratislava

Telefón: 02/52 496046,52496051 - 3

Fax: 07/52 496046

Sčítanie l'udu 1869 [Population census from 1869, historic county Pozsony]

55 villages from one district close to the recent boarder-line, of which one in Hungary, others in Slovakia,

Štátny oblastný archív, Prešov [Regional State Archive in Prešov/Eperjes, SLO]

Slanská 31, 08006 Prešov - Nižná Šebastová

Tel.: 091-7460052 - ústredňa, 091-7460055 - bádatel'ňa

Fax: 091-7764059 
E-mail: archiv@,sapo.vs.sk

Šarišká župa, súpisy obyvatelstva, 1780-1870

Sčítanie obyvatelstva Šž z r. 1869

Sčítacie hárky, 1869 [Population census in county Sáros/Šariš, 1869]

386 settlements, all in Slovakia,

Štátny oblastný archív, Levoča [Regional State Archive in Levoča/Lőcse, SLO]

Námestie Majstra Pavla 7, 60 - 61

05445 Levoča

Telefón: 0966/451 24 24, 45117 65;0966/45124 86, 4511767

Fax: 0966/451 4411

Sčítacie hárky, 1869 [Population census in county Szepes, 1869]

189 villages in historic county Szepes, in Northern Slovakia,

Borsod-Abaúj-Zemplén Megyei Levéltár, Sátoraljaújhelyi Fióklevéltár [Archive of county Borsod-Abaúj-Zemplén in Sátoraljaújhely, HU]

www.bazleveltar.hu

3980 Sátoraljaújhely, Kossuth tér 5.

Tel/fax: +36 47 521-087

E-mail: sauhely@,bazleveltar.hu

XV./83. Zemplén vármegyei 1869. évi népszámlálási iratok gyüjteménye [Collection of population census from 1869 in county Zemplén]

463 settlements partly in Hungary (circa 40), partly in Slovakia (around the other 420) - the historic county Zemplén

Štátny oblastný archív, Banská Bystrica [Regional State Archive in Banska Bystrica/Besztercebánya, SLO]

Komenského 26

97401 Banská Bystrica

Tel.: + $421484152936,+421484154877$

Fax.: +421484152936

Sčítacie hárky, 1869 [Population census in county Zólyom]

120 villages - all in Slovakia in historic county Zólyom,

Tolna Megyei Levéltár [Archive of county Tolna, HU]

www.tolnalev.hu

7100 Szekszárd, Béla király tér 1.

Tel./fax: +36-74/319-473

e-mail: tolnalev@,c3.hu

V.709/c. Bonyhád nagyközség iratai, Közigazgatási iratok [The documents of Bonyhád, Administrative documents]

Boxes 512-513: The census sheets of Bonyhád, 1869

573 houses, entire

Baranya Megyei Levéltár [Archive of county Baranya, HU] 
www.bml.hu

7623 Pécs, Rét u. 9.

Tel.: +36 72 517-350

Fax: +3672 517-358

e-mail: bml@,bml.hu

V.42.d. Mohács város tanácsának iratai, Népszámlálási iratok, 1857-1869 [Documents of the market town Mohács, Census documents, 1857-1869]

Census sheets of Mohács, 1869, 2 boxes

1. houses $1-200$

2. houses $600-1000-$ a fragment (600 houses from circa 2000 , the centre of the town)

\section{Somogy Megyei Levéltár [Archive of county Somogy, HU]}

www.smarchive.hu

7400, Kaposvár, Rippl-Rónai tér 1.

Tel.: +36-82-528-200, +36-82-429-923

fax: $+36-82-314-347$

IV.446. Somogy vármegye Népszámlálási Bizottságának iratai, 1870 [The documents of Somogy county's Census Committee, 1870]

Box 6:

- the census sheets of two villages from the historic county Baranya, in present day Hungary:

Tóthszentgyörgy, 70 houses - entire

Tóthújfalu, 84 houses - entire

- the census sheets of two outskirts of the village Inke, historic county Somogy

Antalfalu - 33 sheets

Fazekasdencs -23 sheets

\section{Heves Megyei Levéltár [Archive of county Heves, HU]}

www.hevesarchiv.hu

3300 Eger, Mátyás király út 62.

Telefon.: +36 320-144, +36 517-343,

Fax: +36 36-517-342

E-mail: hevesarchiv@hevesarchiv.hu

IV.34/1. 854. Population censuses

The census sheets of the village Deménd (Demjén) in county Heves, 1869

190 sheets - almost entire with some missing houses

\section{State Archive of Transcarpathian Oblast (The Ukraine)}

14a Mynaiska Str., Uzhorod, 88005 (building 1)

4 Heroiv Square, Beregove, 90200 (building 2)

Tel./Fax: +380(312) 2-35-49, 2-06-10 (building 1)

Fax: +380 (312) 2-58-39 (building 1)

Tel./Fax: +380(3241) 2-32-10 (building 2)

E-mail: arhiv_uzh@ukr.net

In Beregovo/Beregszász: 
Fond nr.: 7/2. The documents of Ung county's 'alispán' - census sheets from 1869 214 settlements of historic county Ung - more or less entire, to be checked

\section{Later censuses}

Győr-Moson-Sopron Megye Mosonmagyaróvári Levéltára [Archive of county GyőrMoson-Sopron in Mosonmagyaróvár, Hu]

http://www.gyormegy-arch.hu/

9200 Mosonmagyaróvár, Városház u. 4.

Telefon/Fax: +36 96 215-658

V.B.1903.d. Census sheets of the town of Magyaróvár 1925, 1930, 1935, 1940

Censuses of the population made flat by flat, house by house, containing the whole population, above the age 18 by name, under that by number

Data: name of the adults (above 18, married couples and domestic servants, relatives etc.), year of birth, place of birth, profession, since when has he/she lived there, educational status, the time and place of schooling, the number of boys and girls under 18 in the flat

\section{Budapest Főváros Levéltára [The Archive of Budapest]}

http://bfl.archivportal.hu/

1139 Budapest, Teve u. 3-5.

Tel: +36 298-7503, +36 298-7504

E-mail: bfl@,bparchiv.hu

IV.1419.j. Budapest Székesfőváros Statisztikai Hivatalának iratai, az 1941. évi népszámlálás budapesti felvételi és feldolgozási iratainak gyüjteménye [Collection of the documents of Budapest's Statistical Office, collection of the census sheets of Budapest from 1941] 568 boxes - the original sheets of the flats with all inhabitants - circa 1165,000 inhab.

Data: Name, sex, profession, data of the firm owned by the registered person, size of land property, character or title of residence (owner, tenant, their wife, children, relatives, servants etc.), year of birth, marital status, citizenship, religion, mother tongue, nationality, since when has he/she lived in Budapest, when did he/she moved into the given apartment, notes

\section{Fees}

Making scans of the old material is not everywhere allowed. If it is possible then the fee is around 400-500 HUF/page (1,5-2 euro). The price of making photo-copies differs by country: in Slovakia the fee is the same in all state archives (13.27 euro/day). In Hungary the fees are different archive by archive: from $700 \mathrm{HUF}$ (around 2.5 euro/day) up to $2000 \mathrm{HUF} /$ day (around 7 euro). 3000 HUF (Archiepiscopal archive in Kalocsa) or 4000 HUF (Hungarian National Archive in Budapest) are exceptional.

In Romania the fee is 6,5 lei/day (less than 2 euro). 